Article

\title{
Evidence of Carbon Uptake Associated with Vegetation Greening Trends in Eastern China
}

\author{
Zhonghua He ${ }^{1,2,3,4}$, Liping Lei ${ }^{1}$, Zhao-Cheng Zeng ${ }^{5}\left(\mathbb{C}\right.$, Mengya Sheng ${ }^{1,2}$ and Lisa R. Welp ${ }^{3, * \mathbb{C}}$ \\ 1 Key Laboratory of Digital Earth Science, Institute of Remote Sensing and Digital Earth, Chinese Academy of \\ Sciences, Beijing 100094, China; hezhh@radi.ac.cn (Z.H.); leilp@radi.ac.cn (L.L.); shengmy@radi.ac.cn (M.S.) \\ 2 College of Resources and Environment, University of Chinese Academy of Sciences, Beijing 100049, China \\ 3 Department of Earth, Atmospheric, and Planetary Sciences, Purdue University, West Lafayette, \\ IN 47907-2051, USA \\ 4 Zhejiang Climate Center, Hangzhou 310017, China \\ 5 Division of Geological and Planetary Sciences, California Institute of Technology, Pasadena, CA 91125, USA; \\ zcz@gps.caltech.edu \\ * Correspondence: lwelp@purdue.edu
}

Received: 24 December 2019; Accepted: 19 February 2020; Published: 21 February 2020

\begin{abstract}
Persistent and widespread increase of vegetation cover, identified as greening, has been observed in areas of the planet over late 20th century and early 21st century by satellite-derived vegetation indices. It is difficult to verify whether these regions are net carbon sinks or sources by studying vegetation indices alone. In this study, we investigate greening trends in Eastern China (EC) and corresponding trends in atmospheric $\mathrm{CO}_{2}$ concentrations. We used multiple vegetation indices including NDVI and EVI to characterize changes in vegetation activity over EC from 2003 to 2016. Gap-filled time series of column-averaged $\mathrm{CO}_{2}$ dry air mole fraction $\left(\mathrm{XCO}_{2}\right)$ from January 2003 to May 2016, based on observations from SCIAMACHY, GOSAT, and OCO-2 satellites, were used to calculate $\mathrm{XCO}_{2}$ changes during growing season for 13 years. We derived a relationship between $\mathrm{XCO}_{2}$ and surface net $\mathrm{CO}_{2}$ fluxes from two inversion model simulations, CarbonTracker and Monitoring Atmospheric Composition and Climate (MACC), and used those relationships to estimate the biospheric $\mathrm{CO}_{2}$ flux enhancement based on satellite observed $\mathrm{XCO}_{2}$ changes. We observed significant growing period (GP) greening trends in NDVI and EVI related to cropland intensification and forest growth in the region. After removing the influence of large urban center $\mathrm{CO}_{2}$ emissions, we estimated an enhanced $\mathrm{XCO}_{2}$ drawdown during the GP of -0.070 to $-0.084 \mathrm{ppm} \mathrm{yr}^{-1}$. Increased carbon uptake during the GP was estimated to be 28.41 to $46.04 \mathrm{Tg} \mathrm{C}$, mainly from land management, which could offset about $2-3 \%$ of EC's annual fossil fuel emissions. These results show the potential of using multi-satellite observed $\mathrm{XCO}_{2}$ to estimate carbon fluxes from the regional biosphere, which could be used to verify natural sinks included as national contributions of greenhouse gas emissions reduction in international climate change agreements like the UNFCC Paris Accord.
\end{abstract}

Keywords: NDVI; EVI; column $\mathrm{CO}_{2}$; carbon sink; China; satellite

\section{Introduction}

Greening trends appear over much of the global land area [1], indicating changes in ecosystem function at regional scales. Atmospheric carbon dioxide $\left(\mathrm{CO}_{2}\right)$ fertilization, temperature, and precipitation changes account for most of the greening of the Northern Hemisphere (NH) over the past two decades [2-4]. Terrestrial greening in cold climate zones is considered primarily due to warming temperature [5]. Greening may also be caused by the precipitation changes in cool-arid systems like Northern China and Mongolia [6]. In addition to changing climate, vegetation greening 
can also be related to forest regrowth following the abandonment of agricultural lands or plantations [7]. The drivers of greening are fairly well understood and correspond to changes in photosynthetic $\mathrm{CO}_{2}$ uptake [2,4]. However, relating these changes in vegetation indices to changes in net carbon fluxes is challenging, because they are largely insensitive to $\mathrm{CO}_{2}$ release by respiration fluxes [8].

Large-scale land management in certain areas, including agricultural expansion and intensification and afforestation and reforestation efforts, is expected to alter net carbon uptake at the local to regional scales. China's land management policies have promoted both of these practices in recent decades [9-13]. Globally, agricultural production has intensified from the last century to maintain food production for population growth [14,15]. Mixed influences on carbon fluxes have been shown, for example, increased carbon uptake due to longer growing seasons [16] or intensification [17] but stronger carbon emissions from the conversion of natural systems to cultivated crops [18]. Sustainable cropland intensification is necessary for China using available arable land and water [10]. If done properly, it has the potential to reduce greenhouse gas emissions, through careful management of soil, nutrients, and water [19].

Forests are significant contributors to the global terrestrial carbon sink [20], absorbing approximately one-quarter to one-third of the anthropogenic $\mathrm{CO}_{2}$ emissions. Planted forests (afforestation and reforestation) may be used to offset anthropogenic $\mathrm{CO}_{2}$ emissions [21]. Planted forests across China increased significantly at the end of 20th century, increasing the carbon density from 15.3 to 31.1 mega-grams per hectare [22]. Forests planted by China's Grain for Green Program, started in 1999, are estimated to have increased natural carbon sequestration, thereby mitigating $\mathrm{CO}_{2}$ emissions from fossil fuel and cement production [12,13] by about 3-5\% of China's annual carbon emissions (relative to 2010 emissions), which may continue for next 40 years as these forests continue to grow [11]. Even though the precise forest area change is difficult to estimate, the terrestrial carbon sink increase over China is generally accepted $[9,23]$, with a net sink in the range of $0.26 \mathrm{Pg} \mathrm{C}$ per year absorbing $28-37 \%$ of the country's cumulated fossil carbon emissions during the 1980s and 1990s [9,23,24].

In addition to vegetation indices, atmospheric $\mathrm{CO}_{2}$ concentrations using column-averaged $\mathrm{CO}_{2}$ dry air mole fraction $\left(\mathrm{XCO}_{2}\right)$ provide an alternative way to investigate terrestrial biosphere carbon flux changes [25]. $\mathrm{XCO}_{2}$ represents the total amount of $\mathrm{CO}_{2}$ in a vertical column through the atmosphere, and therefore is less sensitive to changes in boundary layer height and surface winds that impact a concentration measurement near the surface without necessarily a corresponding change in local $\mathrm{CO}_{2}$ fluxes. Regional $\mathrm{CO}_{2}$ fluxes have been inferred using satellite observed $\mathrm{XCO}_{2}$ and atmospheric transport models, even though some challenges exist, like satellite observations coverage, systematic errors of the retrievals, and systematic errors of the transport models [26,27]. $\mathrm{XCO}_{2}$ seasonal cycle changes are strongly correlated with vegetation indices from satellite observations from 2009 to $2014[28,29]$. Extremely high $\mathrm{XCO}_{2}$ anomalies are usually accompanied by events such as extreme droughts or floods that reduce vegetation productivity [30,31]. Parazoo et al. [32] found a decrease in tropical $\mathrm{XCO}_{2}$ corresponding to the gross primary production (GPP) increase in the wet season and a $\mathrm{XCO}_{2}$ increase associated with strong biomass burning in dry season in Southern Amazonia. These studies show that $\mathrm{XCO}_{2}$ observations started in 2002 are just beginning to yield insight into variability and trends in surface $\mathrm{CO}_{2}$ fluxes as the records now extend to just over 15 years.

Regional $\mathrm{CO}_{2}$ fluxes have been inferred from satellite-observed $\mathrm{XCO}_{2}$ and in-situ surface observations using atmospheric transport models $[26,27,33]$. Incorporating $\mathrm{XCO}_{2}$ into atmospheric inversions improves upon sparse and location-biased in-situ surface observations and yields estimates that are less sensitive to atmospheric transport model uncertainty [34-36]. It has also been noted that including $\mathrm{XCO}_{2}$ constraints in atmospheric inversions shifts regional biospheric uptake from the tropics to the boreal latitudes [33]. Surface flux estimates from atmospheric inversions are most robust across large scales, like the Transcom regions [37] and diverge at sub-continental scales and smaller [35]. This is due largely to uncertainty in atmospheric transport models and the typically sparse surface $\mathrm{CO}_{2}$ constraints, which may attribute observed atmospheric $\mathrm{CO}_{2}$ anomalies to many different source/sink spatial distributions. In this analysis, we assume that observed localized spatial $\mathrm{XCO}_{2}$ anomalies are likely more sensitive to local surface $\mathrm{CO}_{2}$ fluxes in that specific region than flux estimates derived from 
atmospheric inversions. This is because there is finer spatial resolution in $\mathrm{XCO}_{2}$ observations than estimated inversion $\mathrm{CO}_{2}$ fluxes. Therefore, sub-continental-scale $\mathrm{CO}_{2}$ fluxes may be inferred from $\mathrm{XCO}_{2}$ anomalies directly.

Eastern China (EC) is one area with high densities of vegetation cover and greening trends. Even though there are some modeled carbon sequestration estimates of China's Grain-to-Green Program [11-13], the magnitude of $\mathrm{CO}_{2}$ uptake has not been validated at the regional scale. This study aims to quantify recent trends in regional carbon uptake by quantifying changes in satellite-observed $\mathrm{XCO}_{2}$ during the growing period (GP). We adopt various satellite-observed vegetation parameters to characterize the seasonality and locations of increased vegetation photosynthetic activity in EC and examine $\mathrm{XCO}_{2}$ trends in those regions specifically.

\section{Data and Methods}

Eastern China (EC) mainland, a large carbon storage area in the mid-latitudes [24], was selected for this case study evaluation of carbon uptake trends because it shows persistent vegetation greening (Section 3.1) (outlined in red in Figure 1). Land cover consists of forest, irrigated and rain-fed cropland, and grassland in south $\left(<34^{\circ} \mathrm{N}\right)$ and north $\left(>=34^{\circ} \mathrm{N}\right)$ parts of EC.

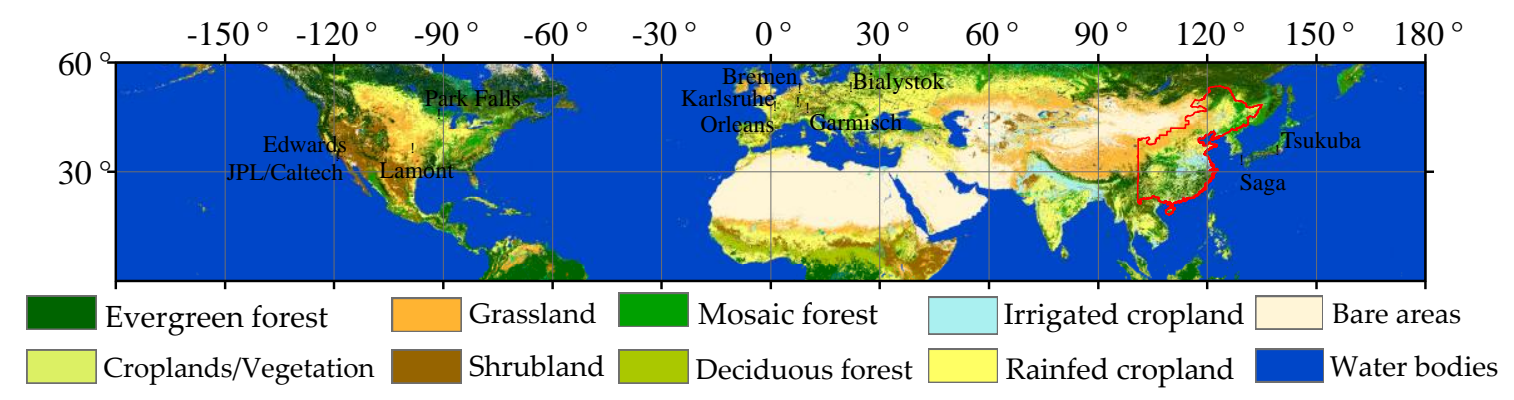

Figure 1. Global land-cover data in 2015 from 0 to $60^{\circ} \mathrm{N}$ obtained from the European Space Agency. Global greening and $\mathrm{XCO}_{2}$ trends are evaluated in Eastern China, shown with red edge for this case study. The names of Total Carbon Column Observing Network (TCCON) measurement sites are labeled (Section 2.4.2).

Datasets used in this research are summarized in Table 1. They include four categories: (1) Vegetation parameters, including normalized difference vegetation index (NDVI), enhanced vegetation index (EVI), leaf area index (LAI), and gross primary production (GPP); (2) $\mathrm{XCO}_{2}$ time series based on observations from multiple greenhouse gas satellites, including Scanning Imaging Absorption spectrometer for Atmospheric Chartography (SCIAMACHY) onboard the Environmental Satellite (ENVISAT), Greenhouse Gases Observing Satellite (GOSAT), and Orbiting Carbon Observatory 2 (OCO-2); (3) $\mathrm{CO}_{2}$ fluxes and corresponding modeled $\mathrm{XCO}_{2}$ concentrations from two inversion models, CarbonTracker (CT) 2017 and Monitoring Atmospheric Composition and Climate (MACC-III), and one forward model GEOS-Chem v11.4; (4) supporting independent datasets, including tree canopy cover percentage (TCCP) and climate factors like land surface temperature (LST) and precipitation, are described in more detail in Section 2.4. 
Table 1. Datasets used in this study.

\begin{tabular}{|c|c|c|c|c|c|}
\hline Name & Sources & Time Res. & Space Res. & Period & Reference \\
\hline NDVI/EVI & MOD13C1 v6 & 16 days & $0.05 \mathrm{deg}$. & \multirow{5}{*}{ 2003.01-2016.12 } & [38] \\
\hline NDVI & GIMMS 3g & 15 days & 1/12 deg. & & [39] \\
\hline LAI & MCD15A3H v6 & 4 days & $500 \mathrm{~m}$ & & [40] \\
\hline LAI & NOAA CDR v4 & 1 day & 0.05 deg. & & [41] \\
\hline GPP & MOD17A2H v6 & 8 days & $500 \mathrm{~m}$ & & {$[42]$} \\
\hline Global maps of $\mathrm{XCO}_{2}$ & $\begin{array}{c}\text { SCIAMACHY } \\
\text { BESD-XCO }{ }_{2} \text { GOSAT } \\
\text { ACOS- } \mathrm{XCO}_{2} \\
\text { OCO-2 } \mathrm{XCO}_{2}\end{array}$ & 8 days & $1 \mathrm{deg}$. & $\begin{array}{l}2003.01-2009.05 \\
2009.06-2014.08 \\
2014.09-2016.05\end{array}$ & $\begin{array}{c}{[43,44]} \\
{[45]} \\
{[46]}\end{array}$ \\
\hline $\mathrm{XCO}_{2} / \mathrm{CO}_{2}$ flux & CarbonTracker 2017 & $3 \mathrm{~h}$ & $2 \times 3 / 1 \times 1 \mathrm{deg}$ & \multirow{3}{*}{ 2003.01-2016.12 } & {$[47]$} \\
\hline $\mathrm{XCO}_{2} / \mathrm{CO}_{2}$ flux & MACC-III & $3 \mathrm{~h}$ & $1.875 \times 3.75 \mathrm{deg}$ & & [48] \\
\hline $\mathrm{XCO}_{2}$ & GEOS-Chem v11.4 & $3 \mathrm{~h}$ & $2 \times 2.5 / 0.5 \times 0.625 \mathrm{deg}$ & & [49] \\
\hline TCCP & AVHRR VCF & Yearly & $0.05 \mathrm{deg}$ & \multirow{4}{*}{ 2003.01-2016.12 } & [50] \\
\hline Fossil fuel $\mathrm{CO}_{2}$ Emission & ODIAC 2017 & monthly & $1 \mathrm{deg}$. & & [51] \\
\hline LST & MCD11C2 v6 & 8 days & 0.05 deg. & & [52] \\
\hline Precipitation & TRMM 3B42 & $3 \mathrm{~h}$ & $0.25 \mathrm{deg}$. & & [53] \\
\hline
\end{tabular}

\subsection{Trends in Regional Vegetation Indices}

\subsubsection{Multiple Vegetation Parameters}

Satellite observed vegetation indices, included normalized difference vegetation index (NDVI) and enhanced vegetation index (EVI) from Moderate-Resolution Imaging Spectroradiometer (MODIS) (MOD13C1 v6) [38] and NDVI from Advanced Very-High-Resolution Radiometer (AVHRR) (GIMMS 3g) [39] were used for greening trend analysis. Leaf area index (LAI), indicating vegetation canopy, from MODIS (MCD15A3H v6) [40] and AVHRR (NOAA CDR v4) [41], were also used for estimating vegetation growth. In addition, GPP (MOD17A2H v6) [42] from MODIS was also used for identifying the trend of photosynthetic productivity.

MOD13C1 v6 was downloaded from National Aeronautics and Space Administration (NASA: https://search.earthdata.nasa.gov/). GIMMS $3 g$ was from National Oceanic and Atmospheric Administration (NOAA: https://data.nodc.noaa.gov/). MCD15A3H v6, MOD17A2H v6, and NOAA CDR v4 were retrieved from Google Earth Engine [54]. NDVI/EVI from MOD13C1 v6, LAI, and GPP were resampled to temporal and spatial resolution of 16 days and $1 \times 1$ degree using bilinear interpolation. NDVI from GIMMS $3 g$ was also integrated to $1 \times 1$ degree.

\subsubsection{Growing Period Identification}

Vegetation indices are widely used to characterize phenology [55-57]. We adopted an exponential and logistical smoothing function [57] to fit EVI time series to quantify the beginning and end of strong vegetation activity as the growing period (GP), shown in Equation (1).

$$
y(t)=\frac{c}{1+e^{a+b t}}+d
$$

where $t$ is time in days, $y(t)$ is the EVI value at time $t, a$ and $b$ are fitting parameters, and $c$ and $d$ were used to constrain the range of EVI values. The spatial/temporal resolution of EVI used here is in $1 \times 1$ degree/16-day. The start/end of GP for each grid cell can be defined as minimum/maximum value of derivation of the curvature of the function fitted to either the early season data or the late season data separately (Figure 2, the period between two red dashed lines). We excluded grid cells with poorly constrained GP from our analysis including those starting after July, ending before April, or extending for longer than 12 months as these are unrealistic results. The start, end, and length of the GP in each grid cell used for the trend analysis shown in Figure S1. The GP length retrieved in EC was $149 \pm 36$ days, which started from day of year $126 \pm 27$ and went to day of year $275 \pm 16$ with longer GP lengths in the south and shorter in the north (Figure S1). 

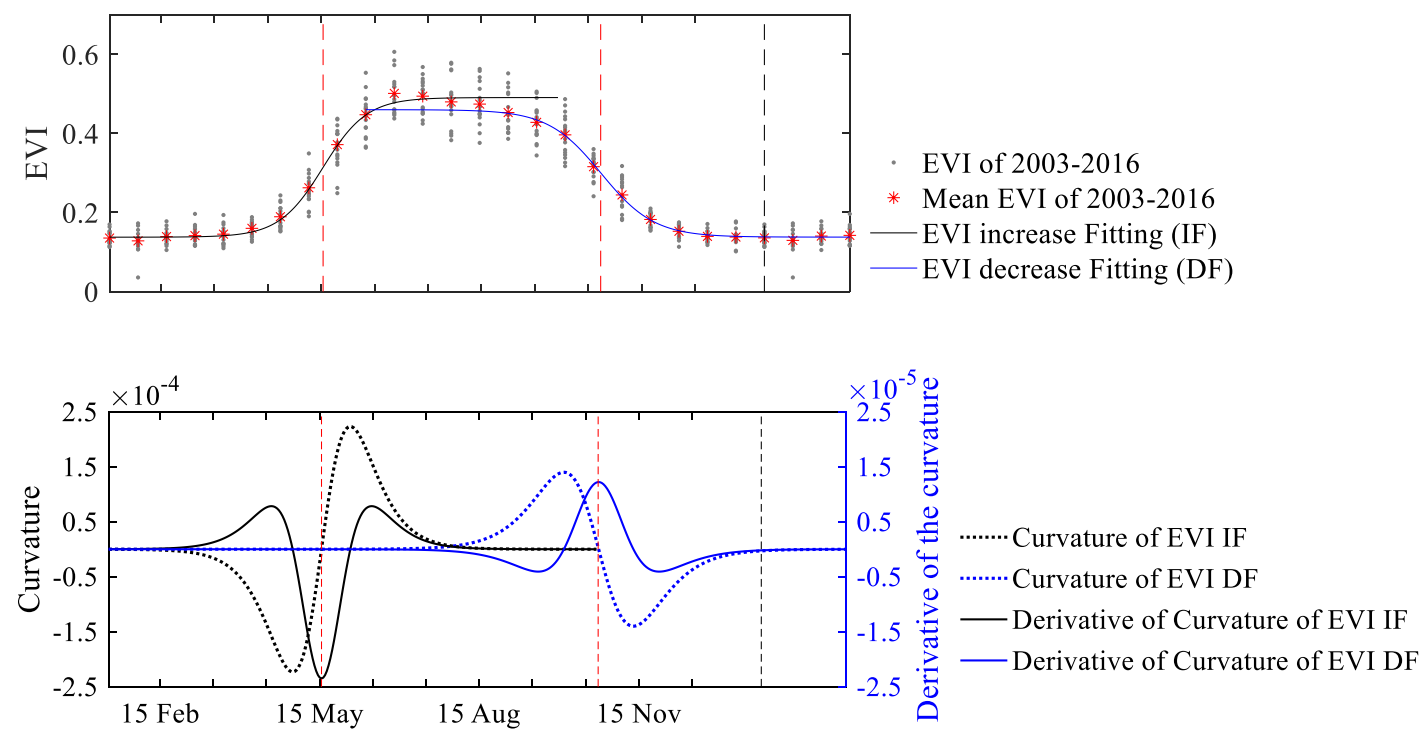

Figure 2. Example of how the growing period is identified from aggregated enhanced vegetation index (EVI) values from 2003 to 2016 data for a single grid cell $\left(\right.$ Lat $=33.5^{\circ} \mathrm{N}$, Lon $=104.5^{\circ} \mathrm{E}$ ). The symbol legends explain the original observations and the mean values. The original EVI values (gray points) for all years, mean seasonal EVI (red points), and EVI fitting results (black for spring increase and blue for fall decrease) are shown in the top panel. Curvature and derivative of the curvature of EVI fitting (black for increase and blue for decrease) are shown in bottom panel. The period between the two red dash lines was identified as the growing period for this grid cell.

\subsubsection{Vegetation Indices Trend Calculation}

We analyzed the trends of multiple vegetation parameters, including NDVI, EVI, and LAI, with a spatial resolution of $1 \times 1$ degree and time resolution of 15-16 days. After the GP was uniquely defined for each grid cell (Section 2.1.2), the mean of the vegetation indices over the fixed GP length for each year in each grid cell was calculated. Interannual trends in mean GP vegetation indices were defined using least-square linear fitting, and the Mann-Kendal test was used to determine statistical significance of the linear trends in each grid cell.

\subsection{Trends in Regional $\mathrm{XCO}_{2}$ Summer Drawdown}

\subsubsection{Satellite-Observed $\mathrm{XCO}_{2}$}

Multiple satellite-observed $\mathrm{XCO}_{2}$ products derived from SCIAMACHY, GOSAT, and OCO-2 platforms were integrated to obtain the longest and most complete record possible [58]. SCIAMACHY on-board the European ENVISAT was launched in 2002, with a temporal resolution of 36 days and spatial resolution of $60 \mathrm{~km}$, available from 2003 to 2012 [59]. GOSAT was launched in 2009 by Japan, with a temporal resolution of 3 days and spatial resolution of $10 \mathrm{~km}$, available from 2009 to the present [60]. NASA's OCO-2 was launched in 2014, with a temporal resolution of 16 days and spatial resolution of $1.29 \times 2.25 \mathrm{~km}$ at nadir, available from 2014 to present [61]. SCIAMACHY XCO $\mathrm{XCO}_{2}$ retrieved by the full-physics based Bremen Optimal Estimation-DOAS (BESD) algorithm (v02.01.01), referred to as BESD-XCO $2[43,44]$ and was downloaded from the European Space Agency (ESA, http://www.esa-ghg-cci.org/). GOSAT was retrieved by the Atmospheric $\mathrm{CO}_{2}$ Observations from Space (ACOS) project team (v7.3), referred to as $A C O S-\mathrm{XCO}_{2}$ [45]. OCO-2 was retrieved by the OCO-2 team (v7r), referred as OCO-XCO $\mathrm{XCO}_{2}$ [46]. ACOS- $\mathrm{XCO}_{2}$ and $\mathrm{OCO}-\mathrm{XCO}_{2}$ were downloaded from NASA (https://disc.gsfc.nasa.gov/). $\mathrm{XCO}_{2}$ from these different observations during 2003 to 2016 was integrated and mapped, described in Section 2.2.2, into global maps of $\mathrm{XCO}_{2}$ (referred as GM-XCO with temporal and spatial resolution of 8 days and $1 \times 1$ degree. 


\subsubsection{Merging and Gap-Filling $\mathrm{XCO}_{2}$ Data Products (Integration and Mapping)}

In order to construct a long-term $\mathrm{XCO}_{2}$ dataset, BESD-XCO $\mathrm{X}_{2}$ from January 2003 to May 2009, ACOS- $\mathrm{XCO}_{2}$ from June 2009 to August 2014, and OCO-XCO ${ }_{2}$ from Sep 2014 to March 2016 were used for $\mathrm{XCO}_{2}$ integration and mapping. $\mathrm{XCO}_{2}$ integration and mapping is the extension of the spatio-temporal geostatistical mapping method applied to multiple satellite observations. Corrections were made to account for differences in vertical measurement sensitivity, differences in satellite overpass times and fields of view, and observation gaps. Steps included: (1) Applying an averaging kernel correction based on vertical profiles from CarbonTracker, (2) normalizing overpass times and unifying spatio-temporal scales of multi-satellite $\mathrm{XCO}_{2}$ data, and (3) global land mapping of $\mathrm{XCO}_{2}$ based on spatio-temporal geostatistics.

In the first step, we corrected for differences in altitude sensitivity of the sensors and normalized the measurements using averaging kernels and a-priori vertical profiles of $\mathrm{CO}_{2}$ from CarbonTracker $\left(\mathrm{CT}-\mathrm{XCO}_{2}\right)$ selected as the common proxy for adjustment (Equation (2)) [43,62].

$$
\mathrm{XCO}_{2 a d j, t}=\mathrm{XCO}_{2 r e t, t}+h^{T}(I-A)\left(X_{M, t}-X_{a, t}\right)
$$

where $\mathrm{XCO}_{2 a d j, t}$ is the adjusted $\mathrm{XCO}_{2}$ value at observation time $t, \mathrm{XCO}_{2 \text { ret }, t}$ corresponds to retrieved $\mathrm{XCO}_{2}$ of $\mathrm{BESD}, \mathrm{ACOS}$, or OCO-2, $h$ and $A$ are the pressure weighting functions and column-averaging kernels from the retrieval algorithm, respectively, $I$ is an identity matrix, $X_{M, t}$ is the common priori $\mathrm{CO}_{2}$ profile from $\mathrm{CT}$, and $\mathrm{X}_{a, t}$ is a priori $\mathrm{CO}_{2}$ profile from satellite retrievals.

Considering the diurnal variability in $\mathrm{XCO}_{2}$ and differences in satellite overpass times, step 2 unified $\mathrm{XCO}_{2}$ from multiple satellites to a common observing local time and spatial resolution. We introduced a scale factor derived from the diurnal variation of $\mathrm{XCO}_{2}$ using $\mathrm{CT}-\mathrm{XCO}_{2}$ to normalize the overpass time of $\mathrm{XCO}_{2}$ retrievals from these three satellites to a reference time (Equation (3)).

$$
\mathrm{XCO}_{2 n o r, t}=\frac{\mathrm{XCO}_{2 \mathrm{CT}, \mathrm{rt}}}{\mathrm{XCO} \mathrm{XCO}_{2 a d, t}}
$$

where $\mathrm{XCO}_{2 n o r, t}$ is the normalized satellite-observed $\mathrm{XCO}_{2}$ at the reference time (rt: 13:00, local time); $\mathrm{XCO}_{2 a d j, t}$ is the adjusted satellite $\mathrm{XCO}_{2}$ derived from Equation (2) at satellite overpass time $t$; $\mathrm{XCO}_{2} \mathrm{CT}, r t$ and $\mathrm{XCO}_{2} \mathrm{CT}, t$ are the $\mathrm{XCO}_{2}$ from CT model at the reference time $r t$ and satellite overpass time $t$, respectively.

Additionally, we unified the different field of views $(30 \times 60 \mathrm{~km}$, diameter of $10.5 \mathrm{~km}$ and $2.25 \times 1.5 \mathrm{~km}$, respectively) and repeat cycles (36 days, 3 days, and 16 days, respectively) of SCIAMACHY, GOSAT, and OCO-2 before using a gap-filling method. In this study, we used a uniform spatio-temporal scale of $30 \times 30 \mathrm{~km}$ as a space unit and 8-day as a time unit to average $\mathrm{XCO}_{2 \text { nor, }}$ of $\mathrm{BESD}-\mathrm{XCO}_{2}, \mathrm{ACOS}-\mathrm{XCO}_{2}$, and $\mathrm{OCO}-\mathrm{XCO}_{2}$ respectively. This uniform spatio-temporal scale was introduced to aggregate different $\mathrm{XCO}_{2}$ data products in order to maintain as much as possible the spatial (regional and national) and temporal (monthly and seasonally) variation of $\mathrm{XCO}_{2}$ observed by these three satellites. The integrated $\mathrm{XCO}_{2}$ dataset in $30 \times 30 \mathrm{~km}$ and 8 days was generated from 2003 to 2016, hereafter referred to as integrated- $\mathrm{XCO}_{2}$. The data quantity and trends of integrated- $\mathrm{XCO}_{2}$ from 2003 to 2016 is shown in Figure S2.

In step 3, we applied a gap-filling interpolation method to the integrated $\mathrm{XCO}_{2}$ to produce continuous global $\mathrm{XCO}_{2}$ maps in time and space. The spatio-temporal geostatistical mapping method, $\mathrm{GM}-\mathrm{XCO}_{2}$, applied in GOSAT observations has been previously used in global carbon research studies $[28,31,63,64]$. Considering the spatial connectivity used in variogram modelling, we divided global land area (within $45^{\circ} \mathrm{S}-60^{\circ} \mathrm{N}$ ) into five continents. As different atmospheric transport exists between hemispheres, Africa was separated into North Africa and South Africa. As a result, modelling the spatio-temporal correlation structure using variograms of $\mathrm{XCO}_{2}$ in the gap-filling method was implemented for each of the six land regions: North America, South America, North Africa, South Africa, Europe, and Asia and Oceania, as shown in Figure S3. Detailed information about the 
spatio-temporal interpolation method can be found in Zeng et al. [63,64]. GM-XCO ${ }_{2}$ from Europe and Asia was used in the $\mathrm{XCO}_{2}$ trend analysis over EC.

$\mathrm{GM}-\mathrm{XCO}_{2}$ data was evaluated using cross-validation (Figure S4) and by comparing to TCCON measurements (Figure S5) $[28,31,64]$. The predicted $\mathrm{XCO}_{2}\left(\mathrm{GM}-\mathrm{XCO}_{2}\right)$ shows a significant linear relationship with the integrated- $\mathrm{XCO}_{2}$ with $\mathrm{R}^{2}=0.97$ ( $p$-value $\left.<0.01\right)$. Good agreement of integrated- $\mathrm{XCO}_{2}$ and the gap-filled GM-XCO 2 is shown by the mean predicted error, mean absolute predicted error, and standard deviation of the error equal to $-0.02,0.99$, and $1.38 \mathrm{ppm}$, respectively.

\subsubsection{Model Simulations of $\mathrm{XCO}_{2}$ and $\mathrm{CO}_{2}$ Fluxes}

Estimated surface $\mathrm{CO}_{2}$ fluxes and $\mathrm{XCO}_{2}$ concentrations from the GEOS-Chem, CarbonTracker, and MACC models were used for two purposes: (1) To create estimates of $\mathrm{XCO}_{2}$ background increase in the study area (Section 2.2.4), and (2) estimate relationships between local surface $\mathrm{CO}_{2}$ fluxes and $\mathrm{XCO}_{2}$ variability (Section 2.3). CarbonTracker (CT) 2017 is a global inversion model from NOAA providing atmospheric $\mathrm{CO}_{2}$ mixing ratio distributions and inferred surface $\mathrm{CO}_{2}$ fluxes with a time resolution of $3 \mathrm{~h}$ [47]. It uses the Carnegie-Ames-Stanford Approach (CASA) land surface model to estimate prior flux estimates and Transport Model 5 (TM5) to represent atmospheric circulation [65]. Optimized posterior surface flux components were solved for with a spatial resolution of $1 \times 1$ degrees including fossil fuel, fire, ocean, and biosphere. Each surface flux was tagged to create associated $\mathrm{CO}_{2}$ concentrations in 25 vertical atmospheric levels with spatial resolution of 2 degrees in latitude and 3 degrees in longitude. The atmospheric pressure of the different levels used was from the CT $\mathrm{CO}_{2}$ total files. Contributions to $\mathrm{XCO}_{2}$ from each component and background concentration were calculated from the vertical profiles based on the pressure-averaged method [66]. MACC-III is also an inversion model from the European Space Agency (ESA) providing global $\mathrm{XCO}_{2}$ and net $\mathrm{CO}_{2}$ fluxes with a temporal and spatial resolution of $3 \mathrm{~h}$ and 1.875 degrees latitude and 3.75 degrees longitude [48]. Both inversion model results have been compared to the FLUXCOM product in Asia [67], but as both are prone to different types of errors and uncertainties, there is no way to provide a robust validation of these model products.

In order to separate local biospheric $\mathrm{CO}_{2}$ flux influence in Eastern China from remote biospheric and other non-biospheric $\mathrm{CO}_{2}$ flux influences on that region, we created estimates of various $\mathrm{CO}_{2}$ flux components using transport model simulations. These simulation results were later used to remove other non-local and non-biospheric influences from observed GM-XCO2 trends using detrending methods. GEOS-Chem is a global 3-D transport model for atmospheric trace gas simulation driven by meteorological and surface flux input [49]. We adopted GEOS-Chem version 11.4 driven by MERRA-2. In the GEOS-Chem global $\mathrm{CO}_{2}$ simulation, we used the CarbonTracker fossil fuel, ocean exchange, and biosphere posterior $\mathrm{CO}_{2}$ fluxes to replace the standard GEOS-Chem surface $\mathrm{CO}_{2}$ flux input. The biomass fire emissions were taken from the Global Fire Emission Database version 4.1s (GFEDv4.1s) [68]. We used annually neutral net terrestrial exchange fluxes and turned off ship and aviation emissions and the 3-D Chemical Oxidized Source. Fossil fuel $\mathrm{CO}_{2}$ emissions used in these tracer models were from the Open-source Data Inventory for Anthropogenic $\mathrm{CO}_{2}$ (ODIAC), which is a global anthropogenic $\mathrm{CO}_{2}$ emission dataset based on estimates made by the Carbon Dioxide Information and Analysis Center (CDIAC) and satellite-observed nightlights and the power plant profile dataset for spatial and temporal distributions [51]. It is monthly data with a spatial resolution of $1 \times 1$ degree.

The global background and a nested GEOS-Chem simulated $\mathrm{XCO}_{2}$ for Eastern Asia (referred as Back-GEOS-XCO 2 and Nested-GEOS-XCO $\mathrm{XC}_{2}$, respectively) were used for local $\mathrm{XCO}_{2}$ background corrections without introducing modeled local biosphere flux variability. In the nested Eastern Asia $\mathrm{CO}_{2}$ simulation, we used the GFED 4.1s land net ecosystem exchange, CarbonTracker biosphere prior $\mathrm{CO}_{2}$ fluxes with annually neutral net $\mathrm{CO}_{2}$ fluxes instead of the CarbonTracker biosphere posterior $\mathrm{CO}_{2}$ fluxes, which are time-varying from year-to-year. The boundary conditions used for the GEOS-Chem nested grid model in eastern Asia at $0.5^{\circ}$ (latitude) $\times 0.625^{\circ}$ (longitude) simulation were provided by the global background model at $2^{\circ}$ (latitude) $\times 2.5^{\circ}$ (longitude) horizontal resolution. We made a restart 
file with 3- $\mathrm{D} \mathrm{CO}_{2}$ concentrations from CarbonTracker at 0:00, on Jan 1 of 2003. The resolution from 25 vertical layers and $2^{\circ} \times 3^{\circ}$ in CT to 47 vertical layers and $2^{\circ} \times 2.5^{\circ}$ in GEOS-Chem, was resampled using the nearest neighbor method. Model $\mathrm{CO}_{2}$ profiles (averages for 12:00-14:00 local time) and the pressure-weighting function described in [66] were used to convert modelled $\mathrm{CO}_{2}$ in discrete layers to $\mathrm{XCO}_{2}$. Temporal mean values of GEOS-Chem background and GEOS-Chem nested simulated $\mathrm{XCO}_{2}$ from 2003 to 2016 over Eastern Asia are shown in Figure S6.

In addition, changes in the sum of $\mathrm{XCO}_{2}$ components $\left(\mathrm{XCO}_{2}\right.$ changes resulting from fossil, fire, biosphere, and ocean $\mathrm{CO}_{2}$ fluxes) from $\mathrm{CT}$ and the MACC-III inversion models were used to estimate relationships between local surface $\mathrm{CO}_{2}$ fluxes and $\mathrm{XCO}_{2}$ variability described in Section 2.3.

\subsection{4. $\mathrm{XCO}_{2}$ Detrending Methods}

To quantify local biosphere-driven changes in $\mathrm{XCO}_{2}$ over time, we need to remove the background $\mathrm{XCO}_{2}$ increase due to sustained fossil fuel emissions and influence from ocean exchange and fire, as well as remote biospheric influence from the study region [69,70]. The precise influence of all non-local non-biospheric processes cannot be directly measured, so we tested four different approaches for defining the background trend to isolate the local biospheric influence in the GM-XCO record. For a first approximation, we adopted the global mean yearly increase from NOAA (https://www.esrl.noaa.gov/gmd/ccgg/trends/gr.html) to build a global background $\mathrm{XCO}_{2}$ increase and applied that uniformly to all grid cells in the study region. The three other detrending methods were based on curve-fitting long-term trends, calculated and applied on a grid cell-by-cell basis. For one, we used the long-term trend $\mathrm{XCO}_{2}$ increase from the gridded $\mathrm{GM}-\mathrm{XCO}_{2}$ observations themselves. In another, we used the fitted $\mathrm{XCO}_{2}$ gridded results from CT-XCO 2 . Finally, we fitted the global background and nested GEOS-Chem simulated $\mathrm{XCO}_{2}$ to clarify the remote influences from the local influences.

The curve-fitting equation applied to each of the three $\mathrm{XCO}_{2}$ records used a combination of a step-wise linear function and annual periodic function as shown in Equation (4).

$$
f(t)=k_{0}+k_{1} t+\sum_{m=1}^{4}\left(a_{i} \cos (2 \pi m t)+b_{i} \sin (2 \pi m t)\right)
$$

Here, $f(t)$ is $\mathrm{XCO}_{2}$ in time $t, k_{0}$ and $k_{1} t$ are treated as the background and cumulated increase of $\mathrm{XCO}_{2}$ in each year, and $\sum_{i=1}^{4}\left(a_{i} \cos (2 \pi m t)+b_{i} \sin (2 \pi m t)\right)$ is used for characterizing the $\mathrm{XCO}_{2}$ seasonal cycle. An example of $\mathrm{GM}-\mathrm{XCO}_{2}$ and $\mathrm{CT}-\mathrm{XCO}_{2}$ fitting of 13 years in one grid cell (Lat: $38.5^{\circ} \mathrm{N}$; Lon: $115.5^{\circ} \mathrm{E}$ ) over EC is shown in Figure 3. Because fitting trends for individual years leads to discontinuities due to the start and end values, we used the mean value of three fitting results using 3 different time windows, starting from 1 December of previous year, 1 January, or 1 February of that year. Example curve fits are shown in Figure 3, but different patterns may be observed at other grid cells. The background $\mathrm{XCO}_{2}$ increase $(y)$ in year $i$ and day $j$ are extracted from the non-seasonal portion of Equation (4) and can be interpolated to daily values using Equation (5).

$$
y_{i, j}=k_{i 0}+\mathrm{k}_{\mathrm{i} 1 * \mathrm{j} / n}
$$

where $k_{i 0}$ and $k_{i 1}$ are the fitted $\mathrm{XCO}_{2}$ background $\left(k_{0}\right)$ and increase ratio $\left(k_{1}\right)$ in year $i$ (from Equation (4) fit), $n$ is the total units in one year (' $365^{\prime}$ used for daily data and ' 46 ' used for data with time resolution of 8 days), and $j$ is the current time step (day or number of 8-day interval). The yearly fitting performed well in global/site $\mathrm{CO}_{2}$ yearly increase with differences of $-0.04 \pm 0.27 \mathrm{ppm}$ for NOAA global mean, $-0.03 \pm 0.13 \mathrm{ppm}$ for global mean of $\mathrm{CT}-\mathrm{XCO}_{2}$, and $-0.06 \pm 0.19 \mathrm{ppm}$ for Mauna Loa shown in Figure S7 and Table S1. 


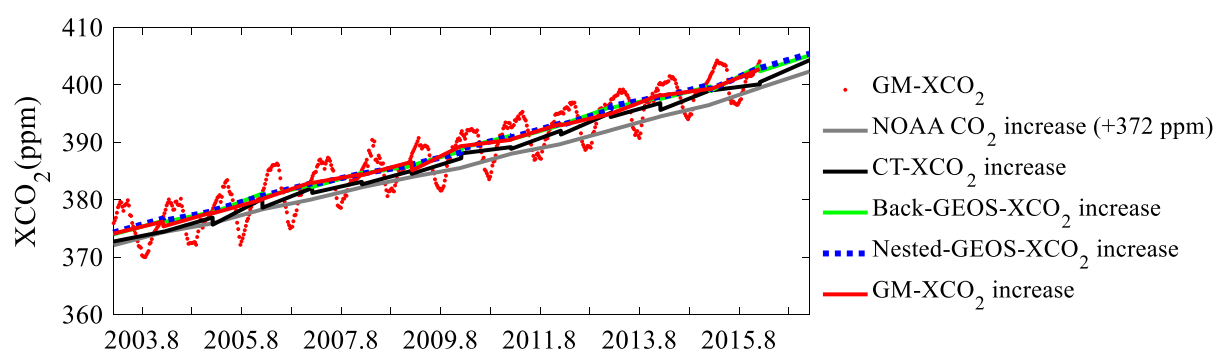

(a) Example of $\mathrm{GM}-\mathrm{XCO}_{2}$ and different background increases in one grid cell

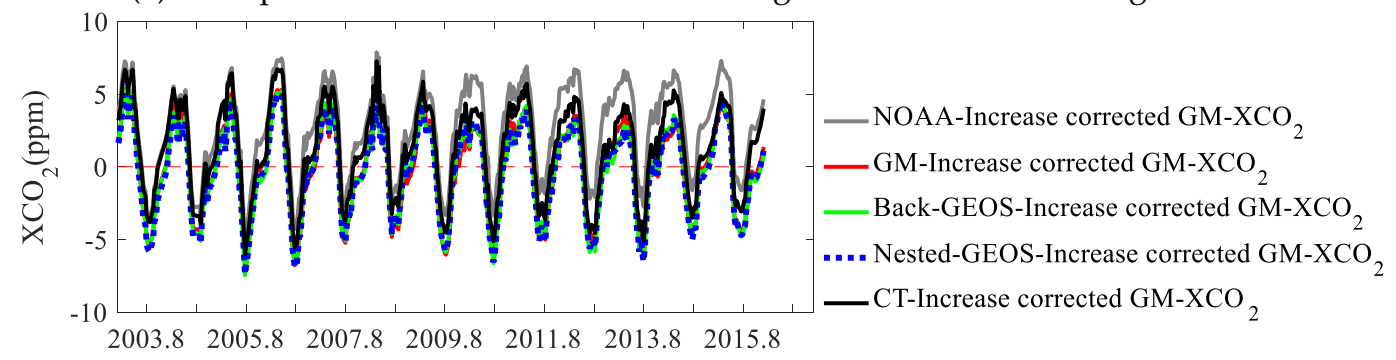

(b) Example background influence corrected GM-XCO 2 in one grid cell

Figure 3. Example of $\mathrm{GM}-\mathrm{XCO}_{2}$ trend "correction" methods aimed at removing remote and local non-biospheric $\mathrm{CO}_{2}$ flux influence from an individual grid cell (Lat: $38.5^{\circ} \mathrm{N}$; Lon: $\left.115.5^{\circ} \mathrm{E}\right)$. (a) $\mathrm{GM}-\mathrm{XCO}_{2}$ (red points) and different $\mathrm{XCO}_{2}$ background characterizations: National Oceanic and Atmospheric Administration (NOAA) surface $\mathrm{CO}_{2}$ increase (grey line) is calculated from the $\mathrm{NOAA}$ mean global $\mathrm{CO}_{2}$ growth rate (+372 ppm), CT-XCO (black line), Back-GEOS- $\mathrm{XCO}_{2}$ (green line), Nested-GEOS- $\mathrm{XCO}_{2}$ (blue dashed line) and $\mathrm{GM}-\mathrm{XCO}_{2}$ increase (red line) are the fitted results using corresponding $\mathrm{XCO}_{2}$ and Equation (4). (b) Corrected $\mathrm{GM}-\mathrm{XCO}_{2}$ time series after removing the background characterizations from panel a. Same color key as above.

\subsubsection{Quantifying $\mathrm{XCO}_{2}$ Trends}

Global detrended GM-XCO ${ }_{2}$ maps derived from integrated and gap-filled satellite observations with temporal and spatial resolution of 8 days and $1 \times 1$ degree were examined for growing period (GP) drawdown trends from 2003 to 2015. The GP was defined for each grid cell using the EVI analysis presented in Section 2.1.2 and the mean GP value of the detrended $\mathrm{GM}-\mathrm{XCO}_{2}$ was calculated for each grid cell and for each year. Least-squares linear fitting and the Mann-Kendal test were used to calculate $\mathrm{XCO}_{2}$ trends and significance for each grid cell.

\subsection{Estimating Surface $\mathrm{CO}_{2}$ Fluxes from $\mathrm{XCO}_{2}$ Variability Based on Correlations in Inversion Models}

$\mathrm{XCO}_{2}$ variability is closely related to surface $\mathrm{CO}_{2}$ fluxes, however quantifying that relationship is challenging due to uncertainties in atmospheric transport and remote versus local $\mathrm{CO}_{2}$ contributions. To estimate the magnitude of the surface flux responsible for observed trends in $\mathrm{XCO}_{2}$, we derived a relationship between surface $\mathrm{CO}_{2}$ fluxes and atmospheric $\mathrm{XCO}_{2}$ from model simulations including CarbonTracker and MACC-III across different time and spatial scales: Daily and 16 days and global and grid cells in EC regions (shown in Figure 1). The total area of selected grid cells in EC shown in Figure S8 is $4.47 \times 10^{12} \mathrm{~m}^{2}$. As the regions become smaller, we expected more noise in the correlations due to transport of $\mathrm{CO}_{2}$ in/out of the region. We also examined the relationship over different time intervals. Daily $\mathrm{XCO}_{2}$ changes were calculated from the difference between two consecutive days and compared to the daily mean $\mathrm{CO}_{2}$ flux. The daily $\mathrm{XCO}_{2}$ and $\mathrm{CO}_{2}$ flux changes from 1 January 2003 to 31 December 2016 in each grid cell were calculated using CT and MACC. XCO 2 changes of several days were defined as the sum of daily changes and $\mathrm{CO}_{2}$ flux changes were defined as total $\mathrm{CO}_{2}$ fluxes of these days. Correlation analysis and least-squares fitting were calculated for the flux- $\mathrm{XCO}_{2}$ relationships (defined as transform ratios) at these different time and space scales. For this analysis of $\mathrm{EC}$, we chose the 16-day correlation over EC to estimate $\mathrm{CO}_{2}$ flux anomalies from $\mathrm{XCO}_{2}$ changes. 


\subsection{Supporting Independent Datatsets}

\subsubsection{Vegetation Coverage Changes}

We compared trends in atmospheric $\mathrm{XCO}_{2}$ to independent evidence of vegetation changes in EC. We adopted tree canopy cover percentage (TCCP) from global vegetation continuous fields (VCF) products by Song et al. [50], which were retrieved from the NASA website (https://search.earthdata. nasa.gov/). This vegetation continuous field was developed using daily satellite AVHRR observations. Tree canopy cover percentage with a spatial resolution of $0.05 \times 0.05$ degree was resampled to $1 \times 1$ degree, same as that of vegetation parameters and $\mathrm{GM}-\mathrm{XCO}_{2}$ used in this analysis.

\subsection{2. $\mathrm{XCO}_{2}$ from $\mathrm{TCCON}$ Measurements}

TCCON is a global network of ground-based Fourier transform spectrometers for atmospheric $\mathrm{XCO}_{2}$ and other trace gases measurements [71]. We compared $\mathrm{GM}-\mathrm{XCO}_{2}$ retrievals to these ground-based measurements to identify potential measurement biases. $\mathrm{XCO}_{2}$ retrievals from TCCON has a high accuracy with approximately $0.25 \%$, which can be used for validation of satellites observed $\mathrm{XCO}_{2}$ [72]. In this study, we selected atmospheric $\mathrm{CO}_{2}$ measurement from TCCON sites with data between 2003.01 to 2016.03 for GM-XCO 2 validation. These sites include Bialystok, Bremen, Karlsruhe, Orleans, Garmisch, Park Falls, Lamont, Tsukuba, Edwards, JPL/Caltech, Saga, Manus, Darwin, Wollongong, and Lauder. Locations of former 11 sites in northern hemisphere are shown in Figure 1, and other the 4 sites (Manus, Darwin, Wollongong, and Lauder) in the southern hemisphere are inside of Brazil, north and south of Australia, and New Zealand, respectively. TCCON measurements from Jan 2003 to Mar 2016, observing local time during 11:00 to 15:00 were used for $\mathrm{XCO}_{2}$ comparison. As a result, there were 3603 pairs of $\mathrm{GM}-\mathrm{XCO}_{2}$ and TCCON XCO ${ }_{2}$, from 15 TCCON sites, used for comparison ( $\mathrm{GM}-\mathrm{XCO}_{2}$ minus TCCON $\left.\mathrm{XCO}_{2}\right)$. $\mathrm{R}^{2}$, mean bias, mean absolute bias, and standard deviation between them were $0.96,0.20,0.90$, and 1.16 , respectively.

\subsubsection{Climate Factors}

Land surface temperature (LST) and precipitation were used for evaluating the effects from climate change in $\mathrm{XCO}_{2}$ change. LST from MODIS (MOD11C2 v6) [52] was downloaded from NASA (https://search.earthdata.nasa.gov/). Precipitation from the Tropical Rainfall Measuring Mission (TRMM) v3B42 [53] was obtained from Google Earth Engine. LST and precipitation were resampled to temporal and spatial resolution of 16 days and $1 \times 1$ degree for correlation analysis with corrected $\mathrm{XCO}_{2}$.

\section{Results}

\subsection{Trends in Regional Vegetation Parameters}

Here, we show mean growing period (GP) vegetation trends for MODIS NDVI and AVHRR NDVI from 2003 to 2016 and AVHRR LAI and tree canopy cover trends from 2003 to 2016 (Figure 4). These vegetation indices are unitless because NDVI and EVI range $0-1$ and LAI is in $\mathrm{m}^{2}$ of leaf area per $\mathrm{m}^{2}$ land surface area. MODIS EVI, LAI, and GPP trends during the GP from 2003 to 2016 are shown in Figure S9. Significant greening trends were observed in EC (Eastern China with red edge) with similar patterns in MODIS NDVI, AVHRR NDVI, and MODIS EVI (Figure 4a,b and Figure S9a). The trends in mean GP values of MODIS NDVI, AVHRR NDVI, and MODIS EVI over EC from 2003 to 2016 were $0.38 \pm 0.27 \times 10^{-2} \mathrm{yr}^{-1}, 0.38 \pm 0.30 \times 10^{-2} \mathrm{yr}^{-1}$, and $0.32 \pm 0.21 \times 10^{-2} \mathrm{yr}^{-1}$, which accounted for $0.70 \pm 0.61 \% \mathrm{yr}^{-1}$ and $0.71 \pm 0.75 \% \mathrm{yr}^{-1}$ of NDVI (MODIS and AVHRR, respectively) and $0.86 \pm 0.60 \% \mathrm{yr}^{-1}$ of EVI relative to the mean values over this 14 -year period. The standard deviation reported here is the variability in all grid cells trends across the EC domain and not an indicator of within-grid cell trend uncertainty. AVHRR LAI also showed significant increasing trends in EC with $0.013 \pm 0.010 \mathrm{~m}^{2} \mathrm{~m}^{-2} \mathrm{yr}^{-1}$ (Figure 4c). In addition, increasing trends $\left(0.009 \pm 0.010 \mathrm{~m}^{2} \mathrm{~m}^{-2} \mathrm{yr}^{-1}\right.$ and $0.11 \pm 0.19 \mathrm{~g} \mathrm{C} \mathrm{m}^{-2} \mathrm{yr}^{-2}$ ) of LAI and GPP from MODIS were also significant in most area of Eastern 
China (Figure S9). Total increases of NDVI and GPP over Eastern China from 2003 to 2015 could be around $8.40 \%$ to $8.52 \%$ and $9.24 \mathrm{~g} \mathrm{C} \mathrm{m}^{-2}$, respectively.

Tree canopy annual trends from 2003 to 2016 showed a strong net increasing trend $\left(0.65 \pm 0.34 \% \mathrm{yr}^{-1}\right)$ in the southern part of EC (Figure $4 \mathrm{~d}$, latitude $<34^{\circ} \mathrm{N}$ ). Large total tree canopy increase from 2003 to $2015(7.80 \%)$, potentially resulting in enhanced photosynthesis rates, may have increased the net carbon sink in this region.

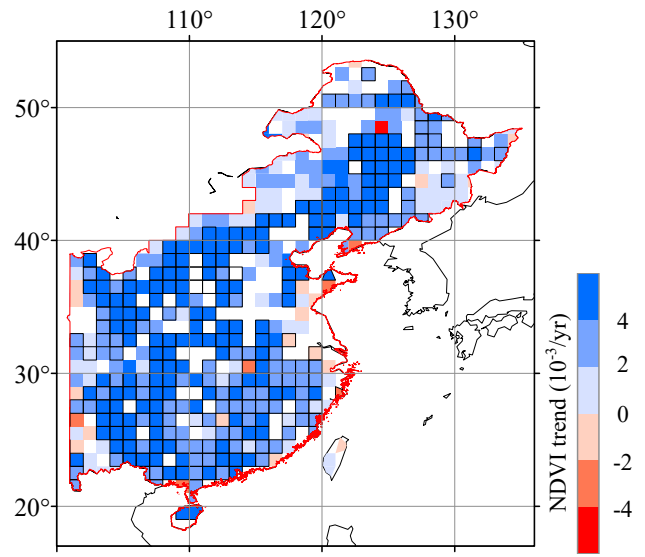

(a) MODIS NDVI yearly trends during GP

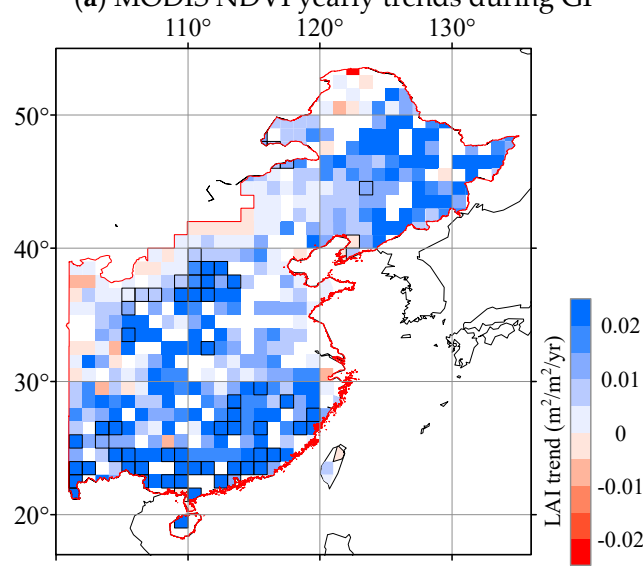

(c) AVHRR LAI yearly trends

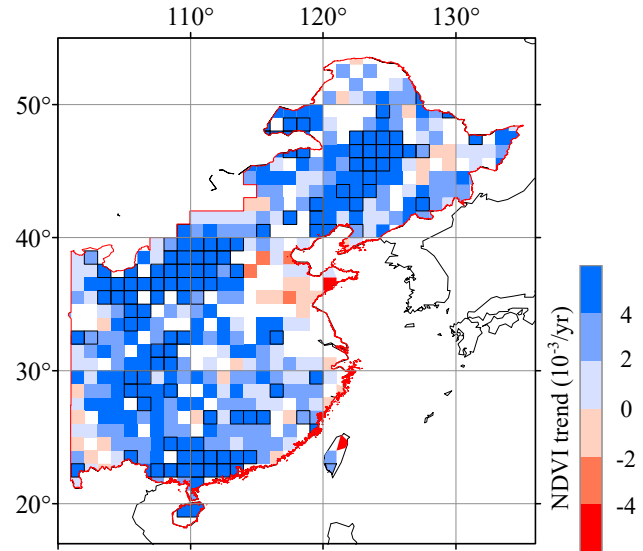

(b) AVHRR NDVI yearly trends during GP

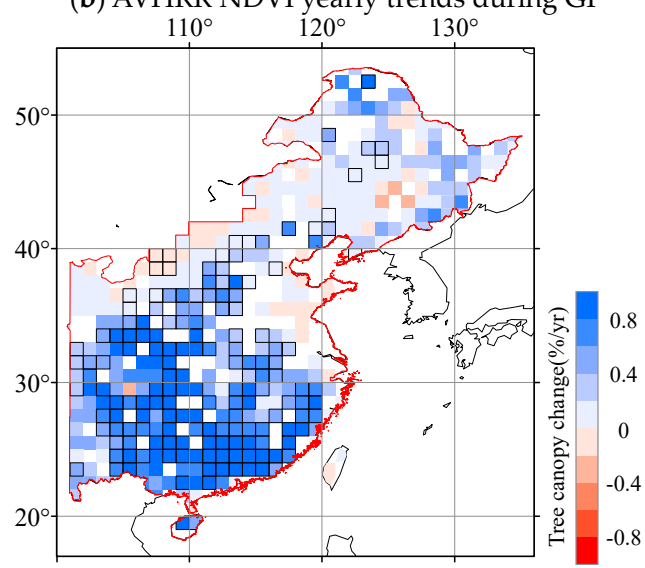

(d) Tree canopy coverage yearly trends

Figure 4. Growing period greening trends from 2003 to 2016 in (a) Moderate-Resolution Imaging Spectroradiometer (MODIS) normalized difference vegetation index (NDVI) and (b) AVHRR NDVI. Annual trends for the same years in (c) Advanced Very-High-Resolution Radiometer (AVHRR) leaf area index (LAI) and (d) tree canopy coverage. Increasing trends are in blue with decreasing trends in red, and grid cells with black outlines indicate trend significance using the Mann-Kendal test $(p<0.05)$. All vegetation indices show significant greening in Eastern China, outlined in red.

\subsection{Trends in Regional $\mathrm{XCO}_{2}$ Summer Drawdown}

Here we identify the trends in $\mathrm{GM}-\mathrm{XCO}_{2}$ that best reflect local biospheric processes in EC and present different methods for removing the influence from fossil fuel and fire emissions and ocean exchange from the observations, and in some cases, remote biospheric influence.

\subsubsection{Satellite Observed $\mathrm{XCO}_{2}$ Trends after Removing Global Mean Growth}

As a first attempt, we removed the NOAA global mean $\mathrm{XCO}_{2}$ growth rate from the GM-XCO order to calculate summer drawdown trends using the mean value of detrended $\mathrm{GM}-\mathrm{XCO}_{2}$ during the GP of each year as shown in Figure 5a. This removed remote influence, the long-term atmospheric growth rate, at each grid cell. Red grid cells with black outlines, indicating significant decreasing 
trends, were observed in some parts of south China $\left(-0.07 \pm 0.05 \mathrm{ppm} \mathrm{yr}^{-1}\right.$ for decreasing grid cells). Blue grid cells with black outlines, indicating significant increasing trends, $0.05 \pm 0.05 \mathrm{ppm} \mathrm{yr}^{-1}$, were observed in some urban regions like Beijing and Shanghai.

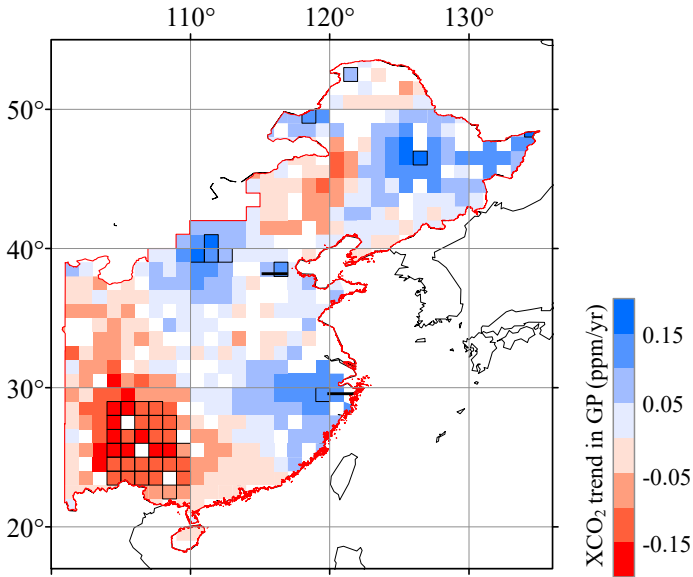

(a) $\mathrm{XCO}_{2}$ trends in GP corrected with NOAA

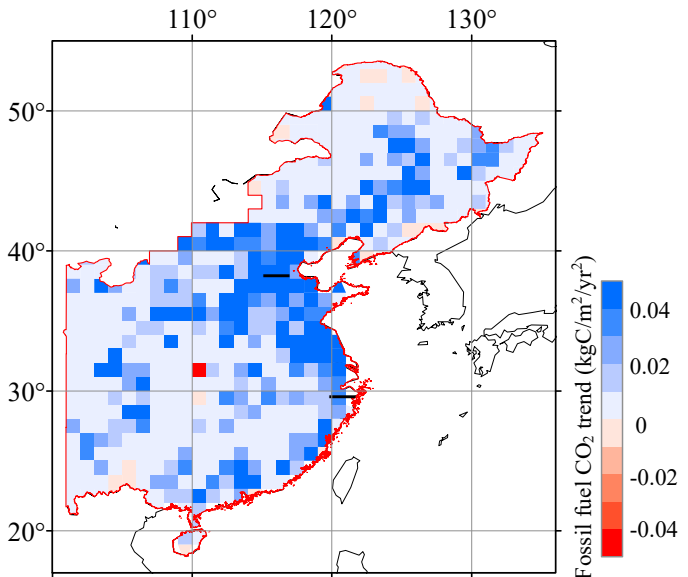

(b) Fossil fuel $\mathrm{CO}_{2}$ emission trend from ODIAC

Figure 5. GM-XCO 2 trends from 2003 to 2015 in growing period corrected with NOAA annual increase (a). Negative values in red indicate an increase in $\mathrm{XCO}_{2}$ drawdown during the growing period. Grid cells with black outlines indicate significant trends (Mann-Kendal test, $p<0.05$ ). Increasing $\mathrm{XCO}_{2}$ values in blue are likely due to a rise in annual fossil fuel emissions in the urban centers of Beijing (North) and Shanghai (South) labeled with black stars. ODIAC fossil fuel $\mathrm{CO}_{2}$ annual emission trends from 2003 to 2016 support this interpretation (b). This $\mathrm{GM}-\mathrm{XCO}_{2}$ trend pattern shows the need to correct for trends in fossil fuel emissions within the study region of Eastern China.

Regions around cites like Beijing and Shanghai showed increasing $\mathrm{XCO}_{2}$ at more extreme rates than the global mean. Blue grid cells indicate $\mathrm{CO}_{2}$ emission increases $\left(0.045 \pm 0.055 \mathrm{~kg} \mathrm{C} \mathrm{m}^{-2} \mathrm{yr}^{-2}\right)$ near urban centers of Eastern Asia in Figure 5a. This is because fossil emissions have increased faster in Beijing and Shanghai than most other regions. Gridded trends in anthropogenic emissions from January 2003 to December 2016 from ODIAC are shown in Figure 5b. Therefore, it is necessary to remove the influence of the local urban $\mathrm{CO}_{2}$ emission domes in order to isolate trends in local biospheric influence on $\mathrm{XCO}_{2}$.

\subsubsection{Satellite-Observed $\mathrm{XCO}_{2}$ Trends after Removing Influence of the Urban $\mathrm{CO}_{2}$ Dome}

In order to remove the influence of increasing anthropogenic emissions from urban centers in our study area, we tested four different spatially variable methods of detrending $\mathrm{GM}-\mathrm{XCO}_{2}$ observations: GM-XCO 2 fitting (Figure 6a), CT- $\mathrm{XCO}_{2}$ fitting (Figure 6b), and GEOS-Chem simulated $\mathrm{XCO}_{2}$ fitting at two different spatial scales: a coarse $2 \times 2.5$ degree lat/lon simulation and a high-resolution nested simulation for Eastern Asia (Figure 6c-d). All methods showed GM- $\mathrm{XCO}_{2}$ residuals decreasing in many EC grid cells from 2003 to 2015 indicating greater $\mathrm{CO}_{2}$ uptake during the GP. For the entire EC domain, detrending the $\mathrm{XCO}_{2}$ time series of each grid by the long-term trend of each grid cell (GM- $\mathrm{XCO}_{2}$ detrending using the full record including growing season and dormant season) resulted in a small trend in the corrected GM-XCO $\mathrm{XCO}_{2}$ during the GP, $-0.058 \pm 0.029 \mathrm{ppm} \mathrm{yr}^{-1}$. The standard deviation reported here is the variability in individual grid cell trends across the EC domain and not an indicator of within grid cell trend uncertainty. This is possible because the annual means and the GP drawdown only can have different trends as seasonal cycles change over time. Detrending using model simulations of $\mathrm{XCO}_{2}$ from remote and local non-biospheric $\mathrm{CO}_{2}$ fluxes resulted in larger GP $\mathrm{CO}_{2}$ uptake trends: $-0.084 \pm 0.090,-0.081 \pm 0.088$, and $-0.070 \pm 0.093 \mathrm{ppm} \mathrm{yr}^{-1}$ (mean \pm 1 standard deviation in space), for $\mathrm{CT}-\mathrm{XCO}_{2}$ and GEOS-Chem coarse and fine resolution, respectively. Of all the grid cells, larger GP $\mathrm{CO}_{2}$ uptake trends were observed in $80 \%, 79 \%$, and $77 \%$ of the grid cells 
depending on the correction method applied, $\mathrm{CT}-\mathrm{XCO}_{2}$ fitting, and GEOS-Chem fittings at coarse and fine resolution, respectively. Grid cells with statistically significant $(p<0.05)$ increasing $\mathrm{GP} \mathrm{CO}_{2}$ uptake trends occupied $40 \%, 41 \%$, and $39 \%$ of EC, respectively. The trends for just the grid cells that showed increased $\mathrm{CO}_{2}$ uptake were $-0.116 \pm 0.067,-0.113 \pm 0.069$, and $-0.108 \pm 0.068 \mathrm{ppm} \mathrm{yr}^{-1}$, respectively (mean \pm 1 standard deviation in space).

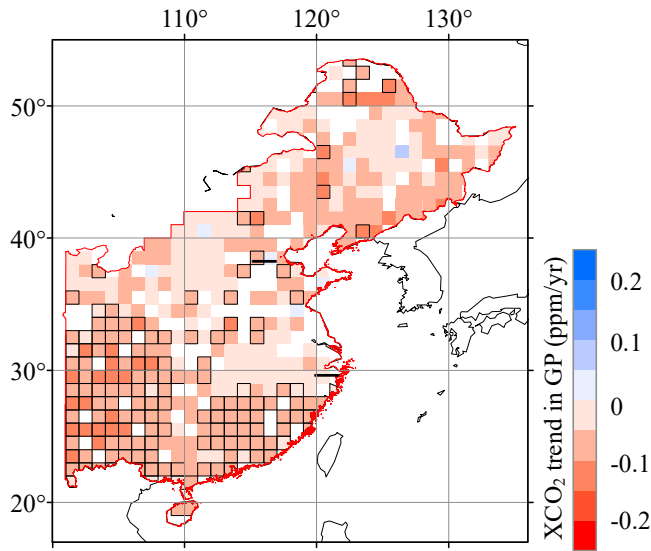

(a) $\mathrm{XCO}_{2}$ trends corrected with GM-XCO 2

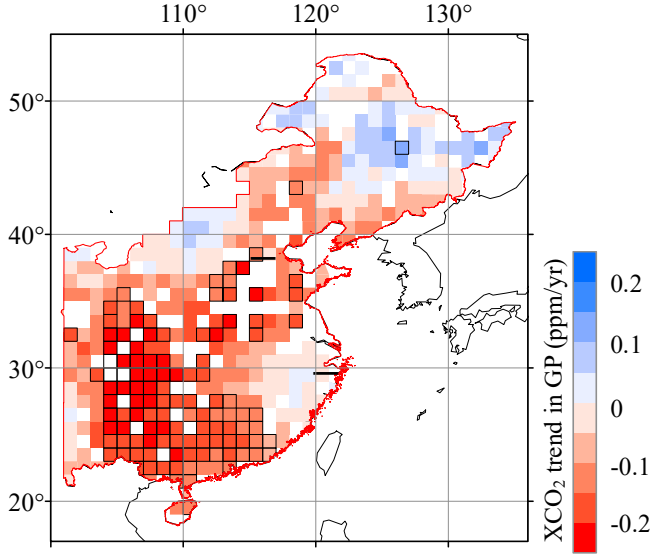

(c) $\mathrm{XCO}_{2}$ trends corrected with GEOS- $\mathrm{XCO}_{2}$

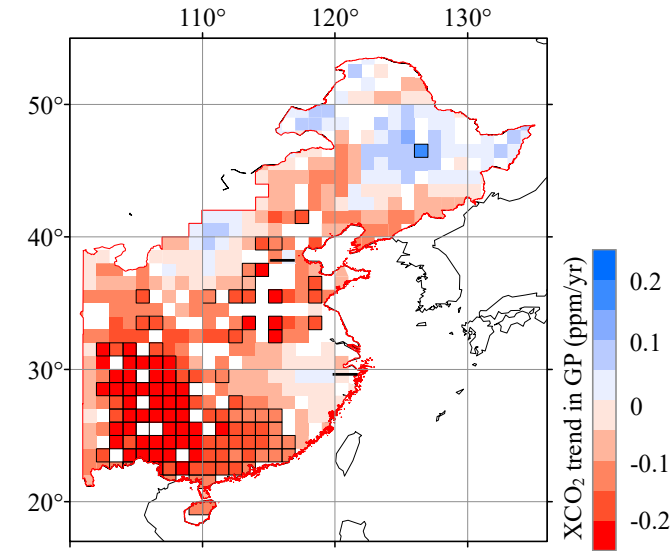

(b) $\mathrm{XCO}_{2}$ trends corrected with $\mathrm{CT}-\mathrm{XCO}_{2}$

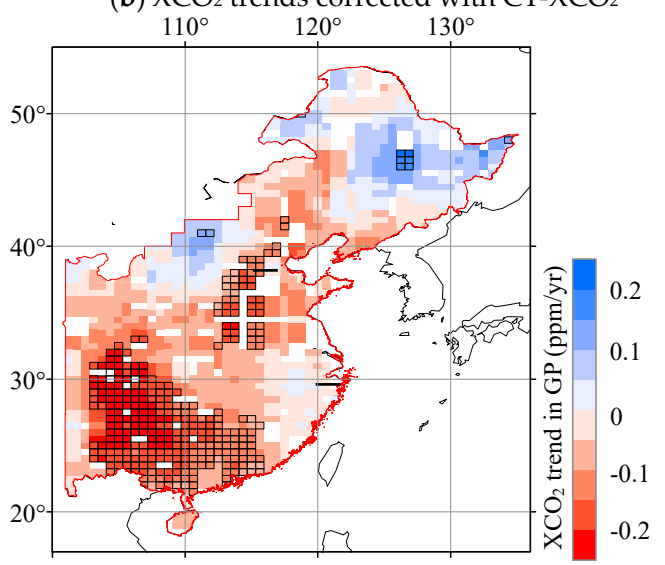

(d) $\mathrm{XCO}_{2}$ trends corrected with nested GEOS- $\mathrm{XCO}_{2}$

Figure 6. $\mathrm{XCO}_{2}$ growing period drawdown trends from 2003 to 2015, after correcting $\mathrm{GM}-\mathrm{XCO}_{2}$ for remote background and local non-biospheric increases in $\mathrm{XCO}_{2}$ by (a) removing the trend from GM-XCO $\mathrm{X}_{2}$ fitting, (b) CT-XCO 2 fitting, (c) background $\mathrm{GEOS}-\mathrm{XCO}_{2}$, (d) and East Asia nested GEOS- $\mathrm{XCO}_{2}$. Red grid cells indicate decreasing trends, or stronger $\mathrm{XCO} 2$ drawdown during the GP and blue grids indicate increasing trends. Grid cells with black outlines in (b), (c), and (d) indicate significant trends within the grid cell (Mann-Kendal test, $p<0.05$ ).

The similar pattern of trends of these last three correction methods showed that there was robust evidence of increased GP $\mathrm{CO}_{2}$ uptake in EC due to biological activity. We consider the corrected GP trend using the GM-XCO ${ }_{2}$ annual increase of $-0.058 \mathrm{ppm} \mathrm{yr}^{-1}$ to be the lower estimate of biospheric influence on $\mathrm{EC} \mathrm{CO}_{2}$ uptake because the local biospheric influence is in the $\mathrm{GM}-\mathrm{XCO}_{2}$ signal itself and a portion of it is removed by the fitting. CT- $\mathrm{XCO}_{2}$ should depict the general pattern of atmospheric $\mathrm{CO}_{2}$ concentration over city areas, as the posterior $\mathrm{CO}_{2}$ concentration and flux from $\mathrm{CT}$ includes fossil fuel emissions and was the optimum estimate of the inversion model.

The spatial patterns of corrected $\mathrm{GM}-\mathrm{XCO}_{2}$ decreases were similar to the increases in vegetation indices, south of the urban centers, shown in Figure 4 and Figure S9a. These results indicate vegetation increases have been accompanied by stronger photosynthesis rates during the GP from 2003 to 2016 and imply increased carbon uptake in EC during the growing season. 


\subsection{Trends in Flux Estimates}

The corrected GM-XCO 2 trends of -0.070 to $-0.084 \mathrm{ppm} \mathrm{yr}^{-1}$ in EC suggest an increased biospheric uptake. In order to estimate the magnitude of the surface $\mathrm{CO}_{2}$ fluxes that would produce that $\mathrm{XCO}_{2}$ anomaly, we used the $\mathrm{CT}$ and MACC models to relate $\mathrm{CO}_{2}$ fluxes to atmospheric $\mathrm{CO}_{2}$ concentration anomalies. We explored correlation between model simulated $\mathrm{XCO}_{2}$ changes daily or over 16 days and net $\mathrm{CO}_{2}$ flux changes in the global or EC region shown in Figure 7. Significant and strong positive correlations were found in the global daily mean data both from CT (Figure $7 \mathrm{a}, \mathrm{R}^{2}=0.84, p<0.01$ ) and MACC (Figure $7 \mathrm{~d}, \mathrm{R}^{2}=0.49, p<0.01$ ) with slopes approaching $0.26 \mathrm{ppm} /\left(\mathrm{g} \mathrm{C} / \mathrm{m}^{2} /\right.$ day) from CT and $0.21 \mathrm{ppm} /\left(\mathrm{g} \mathrm{C} / \mathrm{m}^{2} /\right.$ day $)$ from MACC, where the former was a little larger. The correlation and slopes over EC were much lower than that in the global mean, but still significant (Figure 7b-d). This is because at the global scale, $\mathrm{CO}_{2}$ is conserved during atmospheric transport within the global domain, whereas at the regional domain, transport can be a source or sink of $\mathrm{CO}_{2}$. The correlation decreased as the domain considered got smaller from global to EC. The correlation from daily to 16 days (the time resolution of satellite observed $\mathrm{XCO}_{2}$ and vegetation parameters) became stronger both for CT (Figure 7c) $\left(\mathrm{R}^{2}=0.26, p<0.01\right)$ and MACC (Figure $\left.7 \mathrm{f}\right)\left(\mathrm{R}^{2}=0.23, p<0.01\right)$. The flux- $\mathrm{XCO}_{2}$ transform ratios of 16-day were similar for CT (0.0523 ppm/(g C/m²/16days)) and MACC (0.0465 ppm/(g C/m²/16days)). The correlation became stronger as the time interval increased (from daily to 16-day means), because the influence of persistent $\mathrm{CO}_{2}$ fluxes built up within the domain.

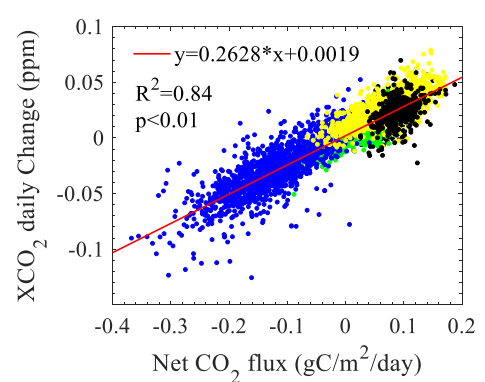

(a) Global Daily from CT

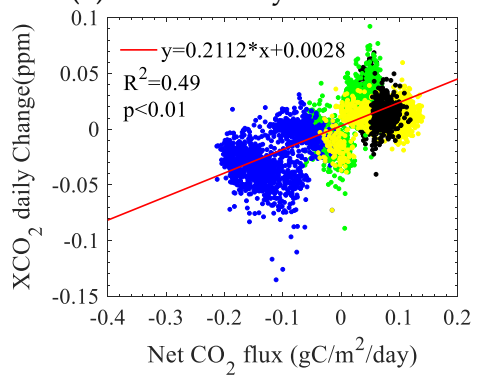

(d) Global Daily from MACC

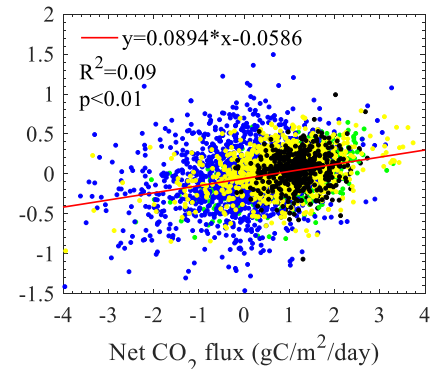

(b) EC daily from CT

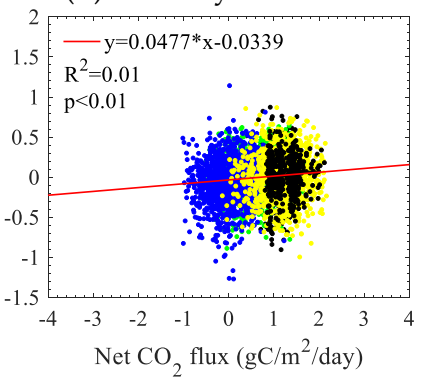

(e) EC daily from MACC

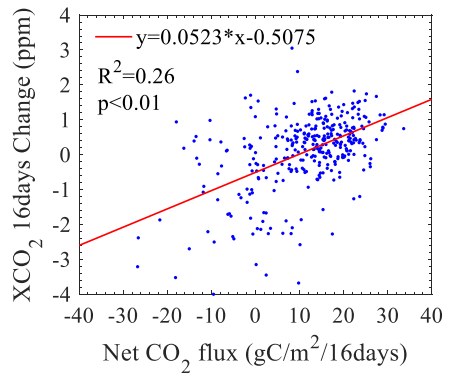

(c) EC 16 days from CT

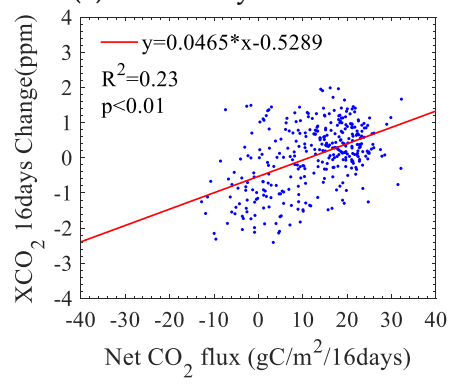

(f) EC 16 days from MACC

- Winter (Dec-Feb)

Figure 7. Estimates of the relationship between $\mathrm{XCO}_{2}$ drawdown and surface $\mathrm{CO}_{2}$ flux magnitudes. Correlation between daily $\mathrm{XCO}_{2}$ changes and daily $\mathrm{CO}_{2}$ flux, from CarbonTracker (CT) and Monitoring Atmospheric Composition and Climate (MACC), for the global mean, (a) for CT and (d) for MACC, and Eastern China (EC), (b) for CT and (e) for MACC. Correlation of 16-day changes over EC is shown in (c) for $\mathrm{CT}$ and (f) for MACC. $\mathrm{XCO}_{2}$ changes are calculated with the $\mathrm{XCO}_{2}$ from adjacent two days (day 2 or day 16 minus day 1 ), and $\mathrm{CO}_{2}$ flux is the mean value of $\mathrm{CO}_{2}$ flux during day 1 or the whole of 16 days. Different colors in (a), (b), (d), and (e) show the $\mathrm{CO}_{2}$ fluxes and concentrations from different seasons (green for March to May, blue for June to August, yellow for September to November, and black for December to February). In our inferred flux estimates, we adopt the 16-day relationship.

We estimated the $\mathrm{CO}_{2}$ flux change from the corrected $\mathrm{GM}-\mathrm{XCO}_{2}$ trends and the model correlation between $\mathrm{XCO}_{2}$ 16-day changes and $\mathrm{CO}_{2}$ flux change shown in Table 2 . The total $\mathrm{XCO}_{2}$ change were 
estimated as $-1.008 \pm 1.080,-0.972 \pm 1.056$, and $-0.840 \pm 1.116 \mathrm{ppm}$ (standard deviation represents spatial variability) from 2003 to 2015 for different correction methods $\left(\mathrm{CT}-\mathrm{XCO}_{2}\right.$ fitting, background GEOS- $\mathrm{XCO}_{2}$ fitting, and nested GEOS-XCO fitting). The inferred carbon uptake increase mean value over the region and its spatial variability were $9.57 \pm 10.94,8.88 \pm 10.48$, and $6.36 \pm 11.63 \mathrm{~g} \mathrm{C} / \mathrm{m}^{2}$ using the CT ppm-to-flux transform ratio and $10.30 \pm 11.85,9.52 \pm 11.33$, and $6.69 \pm 12.62 \mathrm{~g} \mathrm{C} / \mathrm{m}^{2}$ using the MACC transform ratio. That is basically consistent with GPP increase of $9.24 \mathrm{~g} \mathrm{C} \mathrm{m}^{-2}$ shown in Section 3.1. The total carbon uptake amount from 2003 to 2015 ranged from 28.41 to $46.04 \mathrm{Tg} C$ with an EC region area of $4.47 \times 10^{12} \mathrm{~m}^{2}$ shown in Figure S8.

Table 2. GM-XCO 2 decreasing trends and estimated $\mathrm{CO}_{2}$ uptake changes from 2003 to 2015 during the vegetation growing period over Eastern China (EC). There are results from three different $\mathrm{XCO}_{2}$ background corrections and two flux- $\mathrm{XCO}_{2}$ transform ratios. $\mathrm{XCO}_{2}$ background corrections are shown in Section 3.2. Transform ratios are shown in Figure 7. Uncertainties in $\mathrm{XCO}_{2}$ trends and changes refer to 1 standard deviation of spatial grid-scale variability in EC.

\begin{tabular}{|c|c|c|c|c|c|c|}
\hline Attributes $\backslash$ Corrections & \multicolumn{2}{|c|}{$\mathrm{CT}-\mathrm{XCO}_{2}$} & \multicolumn{2}{|c|}{ Back-GEOS-XCO} & \multicolumn{2}{|c|}{ Nested-GEOS-XCO } \\
\hline $\mathrm{XCO}_{2}$ trends $(\mathrm{ppm} / \mathrm{yr})$ & \multirow{2}{*}{\multicolumn{2}{|c|}{$\begin{array}{l}-0.084 \pm 0.090 \\
-1.008 \pm 1.080\end{array}$}} & \multirow{2}{*}{\multicolumn{2}{|c|}{$\begin{array}{l}-0.081 \pm 0.088 \\
-0.972 \pm 1.056\end{array}$}} & \multirow{2}{*}{\multicolumn{2}{|c|}{$\begin{array}{c}-0.07 \pm 0.093 \\
-0.840 \pm 1.116\end{array}$}} \\
\hline $\mathrm{XCO}_{2}$ change (ppm) & & & & & & \\
\hline Transform ratios & $\mathrm{CT}$ & MACC & $\mathrm{CT}$ & MACC & $\mathrm{CT}$ & MACC \\
\hline Carbon uptake increase $\left(\mathrm{g} \mathrm{C} \mathrm{m}^{2}\right)$ & $9.57 \pm 10.94$ & $10.30 \pm 11.85$ & $8.88 \pm 10.48$ & $9.52 \pm 11.33$ & $6.36 \pm 11.63$ & $6.69 \pm 12.62$ \\
\hline Carbon amount $(\operatorname{Tg} C)$ & 42.76 & 46.04 & 39.69 & 42.58 & 28.41 & 29.89 \\
\hline
\end{tabular}

To put this carbon uptake into perspective, we compared it to the carbon exchange inferred from CT during the GP (from day 126 to 275) and the whole year in this region. The averaged biospheric $\mathrm{CO}_{2}$ flux during the GP during 2003 to 2016 over EC was $-99.8 \pm 30.6 \mathrm{~g} \mathrm{C} \mathrm{m}^{-2} \mathrm{yr}^{-1}$ (uncertainty is 1 standard deviation of inter-annual variability). Annual fossil fuel $\mathrm{CO}_{2}$ emission for the same period was $328.48 \pm 91.38 \mathrm{~g} \mathrm{C} \mathrm{m}^{-2} \mathrm{yr}^{-1}$ (uncertainty is 1 standard deviation of inter-annual variability). The satellite-observed total carbon uptake increases from 2003 to 2015 accounted for $6.4 \%$ to $10.3 \%$ of the mean biosphere flux during the GP, approaching the percentage increase in the vegetation indices of $8.4 \%$ to $10.3 \%$ from 2003 to 2015 . This uptake could offset $1.9 \%$ to $3.1 \%$ of annual fossil carbon emissions over that region.

\subsection{Possible Contribution from Climate Variability, Independent of Land Management}

To check the relationship between $\mathrm{XCO}_{2}$ and climate change, we present the Pearson correlation coefficients between corrected $\mathrm{XCO}_{2}$ and MODIS land surface temperature (LST) and TRMM precipitation during the GP from 2003 to 2016 shown in Figure 8. In EC, there was no significant correlation between corrected $\mathrm{XCO}_{2}$ and temperature. This is because vegetation growth is not temperature-limited due to already warm temperatures (Figure S10a) and there were no significant grid-cell trends in LST (Figure S10c). The correlation between corrected $\mathrm{XCO}_{2}$ and precipitation was also not significant. The precipitation in the southern part of EC increased and in the northern part decreased (Figure S10d). A decrease in rainfall in that region was unlikely to result in increased $\mathrm{CO}_{2}$ uptake. Vegetation growth was limited by water in the northern region (Figure S10b), which is why water diversion projects have been constructed to transfer water to the north, therefore disconnecting $\mathrm{CO}_{2}$ uptake from precipitation. Overall, there is no strong support for the observed EC greening trends to be caused by changes in regional temperature and rainfall. It is more likely that greening patterns are driven by increased irrigation in Northeastern China [22,73] and land use change in Southeastern China [74]. 


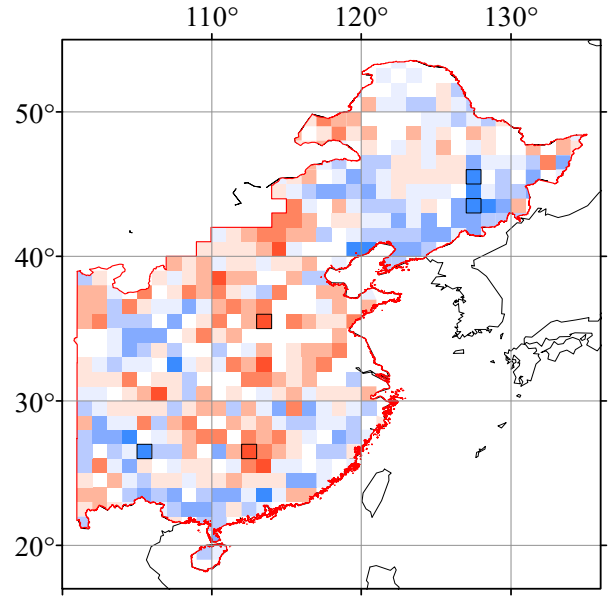

(a) LST

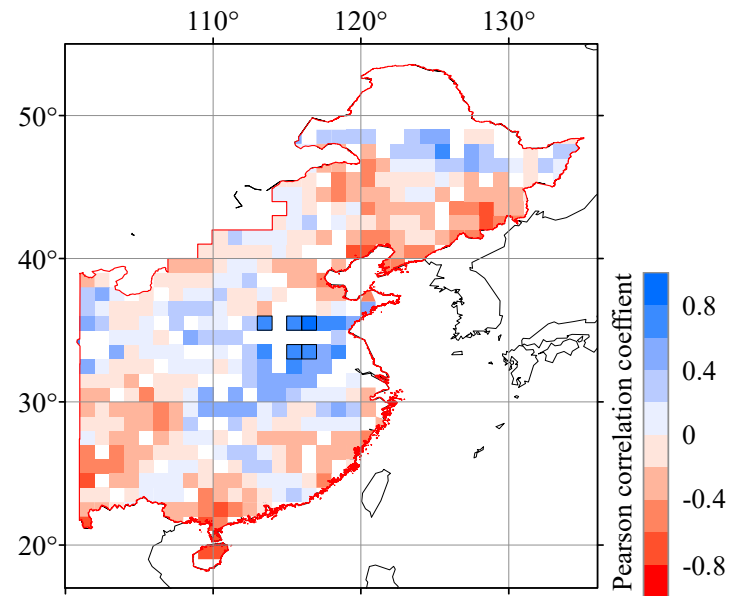

(b) Precipitation

Figure 8. Pearson correlation coefficients between corrected $\mathrm{GM}-\mathrm{XCO}_{2}$ and land surface temperature ((a), LST) and precipitation ((b), Precipitation) in the growing period from 2003 to 2016. The corrected method is using CT-XCO 2 fitting. LST and precipitation were from MODIS (MOD11C2 v6) and TRMM (TRMM 3B42), respectively. Color bar shows the correlation coefficients and grid cells with black outline show grid cells with significant correlations $(p<0.05)$. Observed changes in temperature and precipitation do not effectively explain the observed trends in $\mathrm{GM}-\mathrm{XCO}_{2}$.

\section{Discussion}

Vegetation greening trends (Figure 4) and $\mathrm{XCO}_{2}$ decreasing trends (Figure 6) during the GP show similar patterns of enhanced greening and $\mathrm{CO}_{2}$ uptake in Eastern China (EC). This indicates that enhancements in vegetation activity have had a measurable influence on regional atmospheric $\mathrm{XCO}_{2}$ concentrations due to enhanced $\mathrm{CO}_{2}$ uptake during the GP. Here, we discuss the likely drivers of the vegetation changes we observed, our estimates of the flux changes associated with the $\mathrm{XCO}_{2}$ trend, and consider the uncertainty in our analysis.

\subsection{Different Drivers of Greening in North and South Parts of Eastern China}

Greening trends are observed throughout EC (Figure 4), however the main drivers of these trends are likely different in the north and the south. In the northern part, cropland production has increased significantly from 1987 to 2010 [10] in order to feed the large increase in Chinese population (from 1.08 to 1.34 billion). Increases in agricultural productivity come from increased cropland area $[10,74,75]$ and increased irrigation from water diversion projects moving water from the south to the North China Plain [22,73]. In addition, increased fertilization by nitrogen and phosphorus application [76] and lengthening of the growing period due to warmer temperatures with climate change [77] could provide more nutrients and a longer period of optimal growth conditions.

In the southern part, tree canopy coverage has increased by $9.27 \pm 4.93 \%$ in 2016 from $30.51 \pm 13.90 \%$ in 2003 [50]. Over the last century, widespread deforestation and forest degradation occurred due to conversion to cropland, infrastructure development, mining, fire, and urbanization. During the 21st century, afforestation and reforestation increased significantly in the south part of EC [4], due to governmental policy. Climate conditions over southern EC are suitable for forest growth and expansion to increase carbon uptake with protection provided by land management policies [9].

\subsection{Uncertainty of $\mathrm{GM}-\mathrm{XCO}$ Trends}

The $\mathrm{GM}-\mathrm{XCO}$ product involves merging and gap-filling multiple satellite records (Section 2.2.2), therefore, we need to consider the uncertainty associated with this product. Spurious trends could be caused by the gap-filling method, so we checked the amount of available satellite-observed $\mathrm{XCO}_{2}$ in each grid cell over EC (Figure S11). A greater proportion of observations are distributed in the northern 


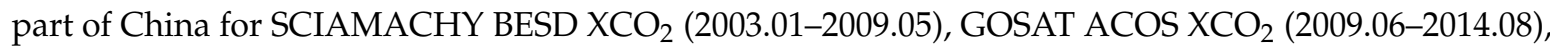
and OCO-2 $\mathrm{XCO}_{2}$ (2014.09-2016.03) because of the cloud contamination discussed earlier. Here, we show the temporal change of integrated $\mathrm{XCO}_{2}$ (the merging of data from the three sensors) and $\mathrm{GM}-\mathrm{XCO}_{2}$ (gap-filled) using available data in EC as shown in Figure 9. GM-XCO integrated $\mathrm{XCO}_{2}$ with a mean difference of $0.25 \pm 1.33 \mathrm{ppm}$. Some differences exist during summer for distinct $\mathrm{XCO}_{2}$ spatial variations shown with mean $\pm 1 \mathrm{STD} G M-\mathrm{XCO}_{2}$ (red dashed lines). We found no significant trend in the GP residuals between integrated $\mathrm{XCO}_{2}$ and the gap-filled $\mathrm{GM}-\mathrm{XCO}_{2}$ using the Mann-Kendal trend test. Therefore, we conclude that the $\mathrm{XCO}_{2}$ decreasing trends are not caused by the gap-filling method.

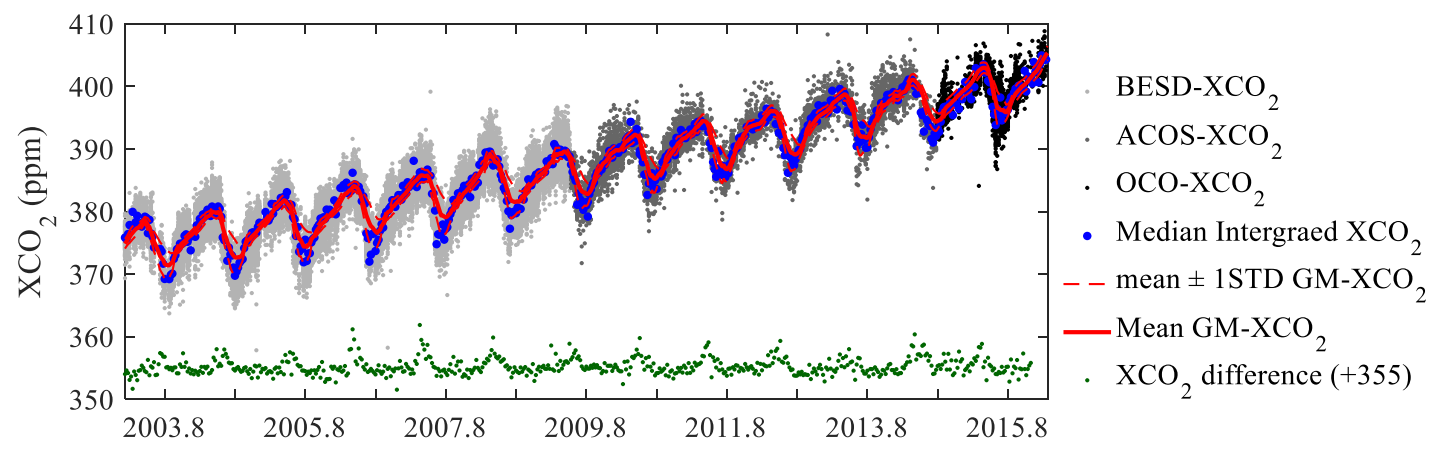

Figure 9. Integrated multi-satellite $\mathrm{XCO}_{2}$ records and $\mathrm{GM}-\mathrm{XCO}_{2}$ over Eastern China. Light gray, dark gray. and black points represent the integrated $\mathrm{BESC}-\mathrm{XCO}_{2}, \mathrm{ACOS}-\mathrm{XCO}_{2}$, and $\mathrm{OCO}-\mathrm{XCO}_{2}$ points from 2003 to 2016 in EC. Blue points are the median value of integrated $X_{C O}$. Red line is the regional mean (solid) GM-XCO \pm 1 STD (dashed). Dark green points are the difference between mean $\mathrm{GM}-\mathrm{XCO}_{2}$ and median integrated $\mathrm{XCO}_{2}$ (+355 ppm).

In addition, we checked the GM- $\mathrm{XCO}_{2}$ product against TCCON measurements as shown in Figure S5. The mean absolute difference (bias) between $\mathrm{GM}-\mathrm{XCO}_{2}$ and TCCON observations with 3608 co-located data pairs was $0.90 \pm 1.16 \mathrm{ppm}$. Individual grid-cell $\mathrm{GM}-\mathrm{XCO}_{2}$ bias followed a Gaussian distribution, therefore the $\mathrm{XCO}_{2}$ uncertainty over EC was estimated as the averaged bias divided by the square root of the number of grid cells in EC. As a result, the uncertainty was less than $0.045 \mathrm{ppm}$, which is significantly less than the $\mathrm{XCO}_{2}$ total change (0.840-1.008 ppm from 2003 to 2016). $\mathrm{XCO}_{2}$ differences between $\mathrm{GM}-\mathrm{XCO}_{2}$ and TCCON measurements from 2003 to 2016 are shown in Figure 10. The differences fluctuate around zero and present no trends from 2003 to 2016 for data pairs in the northern hemisphere. This comparison with the TCCON observations showed that there was no evidence of sensor offsets or drift that would create artificial GM-XCO $\mathrm{X}_{2}$ trends over time.

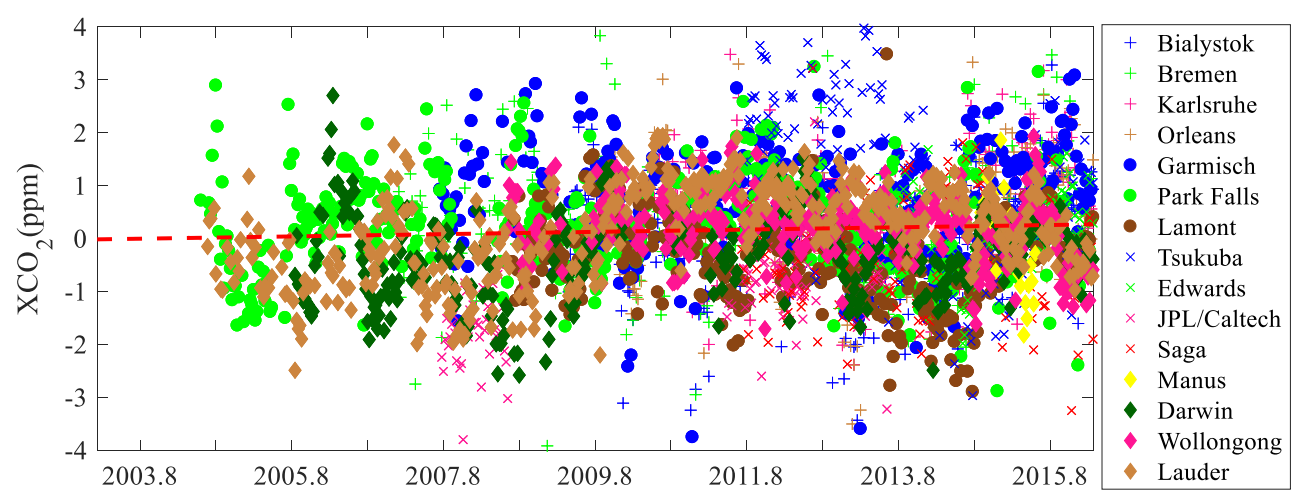

Figure 10. $\mathrm{XCO}_{2}$ difference between $\mathrm{GM}-\mathrm{XCO}_{2}$ and TCCON measurements from 2003 to 2016 using available datasets $\left(\mathrm{GM}-\mathrm{XCO}_{2}\right.$ minus TCCON XCO 2$)$. All GM-XCO $\mathrm{XCl}_{2}$ values within 0.5 degrees around the TCCON sites (different markers) were averaged for the difference calculation. 


\subsection{Uncertainties in Constraining the Urban Dome and Remote Influence on $\mathrm{XCO}_{2}$ Trends}

The $\mathrm{XCO}_{2}$ trends observed over EC result from a combination of remote and local influences. Accurately quantifying the influence of regional biospheric $\mathrm{CO}_{2}$ fluxes in $\mathrm{EC}$ depends on how well we remove the influence from non-local biospheric $\mathrm{CO}_{2}$ fluxes including remote and local anthropogenic fossil and fire emissions and ocean gas exchange as well as remote biospheric influence. In this study, we tested four methods for removing the cumulated $\mathrm{XCO}_{2}$ increase to better study the local biospheric component of $\mathrm{XCO}_{2}$ changes. The first method using the NOAA-reported global mean $\mathrm{CO}_{2}$ is not able to remove the influence from the local urban $\mathrm{CO}_{2}$ dome, which increases over time and therefore underestimated the trend in $\mathrm{XCO}_{2}$ due to local biospheric influence. In addition, the time series fitting of $\mathrm{GM}-\mathrm{XCO}_{2}$ removed the local annual biospheric contribution to the $\mathrm{XCO}_{2}$ trend and underestimated the signal of interest, although there was still a component of GS trends in $\mathrm{XCO}_{2}$ that served as a lower bound of local biospheric influence. The trends calculated from detrending using simulated $\mathrm{XCO}_{2}$ using CT and GEOS-Chem transport (with and without nested grid cells) of CT surface $\mathrm{CO}_{2}$ fluxes were likely the best representation of local biospheric influence on $\mathrm{XCO}_{2}$ because they are designed to remove trends caused by the remote biospheric $\mathrm{CO}_{2}$ fluxes over time, but retain trends in local biospheric $\mathrm{CO}_{2}$ fluxes, plus remove all the non-biospheric influence. Similarities between Figure $6 \mathrm{c}, \mathrm{d}$ showed that characterizing the fine spatial scale resolution of the urban $\mathrm{XCO}_{2}$ dome was not critical to defining GP trends. Therefore, $\mathrm{XCO}_{2}$ decreasing trends of $-0.084 \pm 0.090,-0.081 \pm 0.088$, and $-0.070 \pm 0.093 \mathrm{ppm} \mathrm{yr}^{-1}$ were our best estimates of $\mathrm{XCO}_{2}$ change caused by EC region local biospheric $\mathrm{CO}_{2}$ fluxes with uncertainty listed is the grid-scale spatial variability in trends (Table 2). These trends result in a total $\mathrm{XCO}_{2}$ change from 2003 to 2015 of -0.84 to $-1.01 \mathrm{ppm}$.

This analysis is subject to two sources of bias. First, uncertainty in remote $\mathrm{CO}_{2}$ fluxes could result in artificial trends in local biospheric $\mathrm{CO}_{2}$ fluxes in the study region, however it is very unlikely that such an artificial signal from remote $\mathrm{CO}_{2}$ flux uncertainty would correspond to the exact region that shows vegetation greening. Second, an overestimate in local fossil fuel $\mathrm{CO}_{2}$ emissions from EC in the EDGAR database would result in an overestimate of local biospheric uptake. Saeki and Patra [78] suggested that fossil fuel $\mathrm{CO}_{2}$ emissions in EC may in fact be overestimated based on scaling with methane emissions. There is no independent way to verify local fossil emissions in EC at the moment. However, the correction method based on detrending using annual global mean $\mathrm{CO}_{2}$ concentrations from NOAA supports a local biospheric sink in the southern portion of EC in addition to showing urban emissions increasing faster than the global mean in the northern part (Figure 4a). This correction method cannot create regional artificial biospheric uptake due to local $\mathrm{CO}_{2}$ emissions uncertainty. However, the magnitude of the inferred sink is sensitive to local $\mathrm{CO}_{2}$ emissions uncertainty. This demonstrates the importance of independent constraints of fossil and biospheric $\mathrm{CO}_{2}$ fluxes in order to understand $\mathrm{CO}_{2}$ flux trends near urban centers.

\subsection{Inferred Surface Flux Changes over This Period}

It is predicted that China's investments into environmental improvement has likely increased the forest carbon sink in EC $[9,23,24]$. However, the carbon sink over the East Asian monsoon region is difficult to measure and there is speculation that it has been underestimated [79]. We find the estimated cumulated carbon uptake increases from 2003 to 2015 was in range from 6.36 to $10.30 \mathrm{~g} \mathrm{C} \mathrm{m}^{-2}$ over EC. To understand the significance of these changes, we compare with mean posterior flux estimates from CT (Table 3). The carbon sink increase is equivalent to $9.0 \%$ to $14.6 \%$ of the annual biospheric flux over $\mathrm{EC}$ and equivalent to offsetting about 1.9-3.1\% of EC's annual fossil fuel $\mathrm{CO}_{2}$ emissions. By comparison, the increased carbon uptake during the GP was slightly underestimated in the interannually varying CT posterior $\mathrm{CO}_{2}$ fluxes, which is about $6.4 \%$ to $10.3 \%$ of regional CT posterior annual biopsheric flux.

In this estimation, we calculated the biospheric $\mathrm{CO}_{2}$ flux trend during the GP only, not including the dormant season. It is possible that carbon release during the dormant season could cancel some of the carbon uptake gains made in the GP. We tested $\mathrm{XCO}_{2}$ trends in the dormant season, after CT-XCO correction (Figure S12), but find no significant trends in EC. It is possible that this carbon sink could 
saturate in the future as the forests mature and agricultural intensification peaks [80]. These could be evaluated with continuous observations.

Table 3. Comparison of the estimated carbon uptake increase ( 6.36 to $10.30 \mathrm{~g} \mathrm{C} \mathrm{m}^{-2}$ ) due to greening with various posterior $\mathrm{CO}_{2}$ fluxes inferred from $\mathrm{CT} 2017$ for the region during the growing period (GP) and the whole year. Posterior $\mathrm{CO}_{2}$ fluxes include the net flux, biosphere (Bio) flux, and fossil fuel emissions of annual mean and inter-annual variation. Negative values indicate carbon uptake and positive values indicate carbon emission. Values in parentheses compare the $\mathrm{CO}_{2}$ sink enhancement as percentages of the various GP CT CO 2 fluxes.

\begin{tabular}{cccc}
\hline Period & Net Flux $\left(\mathbf{g ~ C ~}^{-\mathbf{2}} \mathbf{y r}^{-\mathbf{1}}\right)$ & Bio Flux $\left(\mathbf{g ~ C ~}^{-\mathbf{2}} \mathbf{y r}^{-\mathbf{1}}\right)$ & Fossil Flux $\left(\mathbf{g ~ C ~}^{-\mathbf{2}} \mathbf{~ y r}^{-\mathbf{1}}\right)$ \\
\hline \multirow{2}{*}{ GP } & $28.0 \pm 54.5$ & $-99.8 \pm 30.6$ & $125.7 \pm 34.8$ \\
& $(22.6 \%$ to $36.7 \%)$ & $(6.4 \%$ to $10.3 \%)$ & $(5.1 \%$ to $8.2 \%)$ \\
\hline \multirow{2}{*}{ Annual } & $264.15 \pm 109.85$ & $-70.77 \pm 36.76$ & $328.48 \pm 91.38$ \\
& $(2.4 \%$ to $3.9 \%)$ & $(9.0 \%$ to $14.6 \%)$ & $(1.9 \%$ to $3.1 \%)$ \\
\hline
\end{tabular}

The method used here to infer flux changes is different from atmospheric inversion approaches [26,27] and more recent Lagrangian methods $[81,82]$ to link surface $\mathrm{CO}_{2}$ fluxes to atmospheric $\mathrm{CO}_{2}$ observations. Our approach may likely underestimate the surface $\mathrm{CO}_{2}$ sink strength as some of the negative $\mathrm{CO}_{2}$ anomaly is transported out of the study domain. However, it is unlikely that an anomaly caused by a $\mathrm{CO}_{2}$ sink outside of the domain is transported inside because of the distribution of vegetation in this region. This analysis should be viewed as an independent method with a different sensitivity to atmospheric transport uncertainty.

\section{Conclusions}

Significant greening trends in Eastern China were observed by various parameters including NDVI trends of $0.70 \pm 0.61 \% \mathrm{yr}^{-1}$ (MODIS) and $0.71 \pm 0.75 \% \mathrm{yr}^{-1}$ (AVHRR) and an EVI trend of $0.86 \pm 0.60 \% \mathrm{yr}^{-1}$ (MODIS). Greening trends over the northern and southern parts of EC are consistent with increased cropland area and production increase in north, and forest canopy increase in south. These have previously been attributed to the national policies of sustainable development, including intensification of agriculture and afforestation and reforestation as part of China's Grain-to-Green program [2]. Here, we show that these greening patterns are consistent with increased growing season $\mathrm{CO}_{2}$ uptake in this region.

Satellite-observed $\mathrm{XCO}_{2}$ trends showed a corresponding increase in the carbon sink in the region of greening in EC. Significant $\mathrm{XCO}_{2}$ decreases attributable to local biospheric influence during the growing period were shown using different correction methods to remove non-local, non-biospheric influence. Averaged $\mathrm{XCO}_{2}$ trends across EC varied from -0.070 to $-0.084 \mathrm{ppm} \mathrm{yr}^{-1}$. Estimated local $\mathrm{CO}_{2}$ uptake increases were 6.36 to $10.30 \mathrm{~g} \mathrm{C} \mathrm{m}^{-2}$ over EC during the growing period, which is consistent with a MODIS observed GPP increase of $9.24 \mathrm{~g} \mathrm{C} \mathrm{m}^{-2}$. These fluxes accounted for 6.4 to $10.3 \%$ of the mean biosphere flux during the GP, which is similar to percent increases in vegetation indices, 8.40 to $10.32 \%$ from 2003 to 2015 . The total carbon uptake increase ranged from 28.41 to $46.04 \mathrm{Tg}$ C. That could offset about 2-3\% of EC's annual fossil fuel emissions. Integrated data from multiple greenhouse satellite (SCIAMACHY, GOSAT, OCO-2 or the recently launched Tansat) observations could provide a valuable method for estimating regional $\mathrm{CO}_{2}$ flux change.

Supplementary Materials: The following are available online at http://www.mdpi.com/2072-4292/12/4/718/s1.

Author Contributions: Conceptualization, L.R.W. and Z.H.; methodology, L.R.W. and Z.H.; formal analysis, L.R.W., Z.H. and L.L.; software, L.L., Z.-C.Z., and M.S.; writing-original draft preparation, Z.H. and L.R.W.; writing-review and editing, L.R.W., Z.H. and L.L. All authors have read and agreed to the published version of the manuscript.

Funding: This research was funded by the National Key Research and Development Program of China (2016YFA0600303), the Strategic Priority Research Program of the Chinese Academy of Sciences (XDA19080303) 
and the Key Research Program of Chinese Academy of Sciences (ZDRW-ZS-2019-3). Z.H. was supported by a University of Chinese Academy of Sciences (UCAS) Joint Ph.D. Program scholarship.

Acknowledgments: We thank Prabir Patra for productive conversations regarding this analysis. We also thank ESA for sharing the SCIAMACHY BESD XCO 2 level 2 data, the ACOS/OCO-2 project at JPL for sharing ACOS-GOSAT v7.3 and OCO-2 v7r data, NOAA ESRL for proving CarbonTracker CT2017 results, and ECMWF for providing MACC-III results. We thank NASA, NOAA, and Google Earth Engine for providing vegetation indices.

Conflicts of Interest: The authors declare no conflict of interest.

\section{References}

1. Zhu, Z.; Piao, S.; Myneni, R.B.; Huang, M.; Zeng, Z.; Canadell, J.G.; Ciais, P.; Sitch, S.; Friedlingstein, P.; Arneth, A.; et al. Greening of the Earth and its drivers. Nat. Clim. Chang. 2016, 6, 791-795. [CrossRef]

2. Chen, C.; Park, T.; Wang, X.; Piao, S.; Xu, B.; Chaturvedi, R.K.; Fuchs, R.; Brovkin, V.; Ciais, P.; Fensholt, R.; et al. China and India lead in greening of the world through land-use management. Nat. Sustain. 2019, 2, 122-129. [CrossRef] [PubMed]

3. Piao, S.; Friedlingstein, P.; Ciais, P.; Zhou, L.; Chen, A. Effect of climate and $\mathrm{CO}_{2}$ changes on the greening of the Northern Hemisphere over the past two decades. Geophys. Res. Lett. 2006, 33. [CrossRef]

4. Piao, S.; Yin, G.; Tan, J.; Cheng, L.; Huang, M.; Li, Y.; Liu, R.; Mao, J.; Myneni, R.B.; Peng, S.; et al. Detection and attribution of vegetation greening trend in China over the last 30 years. Glob. Chang. Biol. 2015, 21, 1601-1609. [CrossRef]

5. Nemani, R.R.; Keeling, C.D.; Hashimoto, H.; Jolly, W.M.; Piper, S.C.; Tucker, C.J.; Myneni, R.B.; Running, S.W. Climate-Driven Increases in Global Terrestrial Net Primary Production from 1982 to 1999. Science 2003, 300, 1560-1563. [CrossRef]

6. Poulter, B.; Pederson, N.; Liu, H.; Zhu, Z.; D’Arrigo, R.; Ciais, P.; Davi, N.; Frank, D.; Leland, C.; Myneni, R.; et al. Recent trends in Inner Asian forest dynamics to temperature and precipitation indicate high sensitivity to climate change. Agric. For. Meteorol. 2013, 178, 31-45. [CrossRef]

7. Xiao, J.; Moody, A. Geographical distribution of global greening trends and their climatic correlates: 1982-1998. Int. J. Remote Sens. 2008, 26, 2371-2390. [CrossRef]

8. Piao, S.; Wang, X.; Park, T.; Chen, C.; Lian, X.; He, Y.; Bjerke, J.W.; Chen, A.; Ciais, P.; Tømmervik, H.; et al. Characteristics, drivers and feedbacks of global greening. Nat. Rev. Earth Environ. 2019, 1, 14-27. [CrossRef]

9. Ahrends, A.; Hollingsworth, P.M.; Beckschäfer, P.; Chen, H.; Zomer, R.J.; Zhang, L.; Wang, M.; Xu, J. China's fight to halt tree cover loss. Proc. R. Soc. B Biol. Sci. 2017, 284. [CrossRef]

10. Zuo, L.; Zhang, Z.; Carlson, K.M.; MacDonald, G.K.; Brauman, K.A.; Liu, Y.; Zhang, W.; Zhang, H.; Wu, W.; Zhao, X.; et al. Progress towards sustainable intensification in China challenged by land-use change. Nat. Sustain. 2018, 1, 304-313. [CrossRef]

11. Deng, L.; Liu, S.; Kim, D.G.; Peng, C.; Sweeney, S.; Shangguan, Z. Past and future carbon sequestration benefits of China's grain for green program. Glob. Environ. Chang. 2017, 47, 13-20. [CrossRef]

12. Liu, D.; Chen, Y.; Cai, W.; Dong, W.; Xiao, J.; Chen, J.; Zhang, H.; Xia, J.; Yuan, W. The contribution of China's Grain to Green Program to carbon sequestration. Landsc. Ecol. 2014, 29, 1675-1688. [CrossRef]

13. Persson, M.; Moberg, J.; Ostwald, M.; Xu, J. The Chinese Grain for Green Programme: Assessing the carbon sequestered via land reform. J. Environ. Manag. 2013, 126, 142-146. [CrossRef] [PubMed]

14. Foley, J.A.; Ramankutty, N.; Brauman, K.A.; Cassidy, E.S.; Gerber, J.S.; Johnston, M.; Mueller, N.D.; O'Connell, C.; Ray, D.K.; West, P.C.; et al. Solutions for a cultivated planet. Nature 2011, 478, 337-342. [CrossRef]

15. Matson, P.A.; Parton, W.J.; Power, A.G.; Swift, M.J. Agricultural Intensification and Ecosystem Properties. Science 1997, 277, 504-509. [CrossRef]

16. Reyes-Fox, M.; Steltzer, H.; Trlica, M.J.; McMaster, G.S.; Andales, A.A.; LeCain, D.R.; Morgan, J.A. Elevated $\mathrm{CO}_{2}$ further lengthens growing season under warming conditions. Nature 2014, 510, 259-262. [CrossRef]

17. Gray, J.M.; Frolking, S.; Kort, E.A.; Ray, D.K.; Kucharik, C.J.; Ramankutty, N.; Friedl, M.A. Direct human influence on atmospheric $\mathrm{CO}_{2}$ seasonality from increased cropland productivity. Nature 2014, 515, 398-401. [CrossRef] 
18. Baumann, M.; Gasparri, I.; Piquer-Rodriguez, M.; Gavier Pizarro, G.; Griffiths, P.; Hostert, P.; Kuemmerle, T. Carbon emissions from agricultural expansion and intensification in the Chaco. Glob. Chang. Biol. 2017, 23, 1902-1916. [CrossRef]

19. Burney, J.A.; Davis, S.J.; Lobell, D.B. Greenhouse gas mitigation by agricultural intensification. Proc. Natl. Acad. Sci. USA 2010, 107, 12052-12057. [CrossRef]

20. Canadell, J.G.; Raupach, M.R. Managing forests for climate change mitigation. Science 2008, 320, $1456-1457$. [CrossRef]

21. Zomer, R.J.; Trabucco, A.; Bossio, D.A.; Verchot, L.V. Climate change mitigation: A spatial analysis of global land suitability for clean development mechanism afforestation and reforestation. Agric. Ecosyst. Environ. 2008, 126, 67-80. [CrossRef]

22. Fang, Q.; Ma, L.; Yu, Q.; Ahuja, L.R.; Malone, R.W.; Hoogenboom, G. Irrigation strategies to improve the water use efficiency of wheat-maize double cropping systems in North China Plain. Agric. Water Manag. 2010, 97, 1165-1174. [CrossRef]

23. Ouyang, Z.; Zheng, H.; Xiao, Y.; Polasky, S.; Liu, J.; Xu, W.; Wang, Q.; Zhang, L.; Xiao, Y.; Rao, E. Improvements in ecosystem services from investments in natural capital. Science 2016, 352, 1455. [CrossRef] [PubMed]

24. Piao, S.; Fang, J.; Ciais, P.; Peylin, P.; Huang, Y.; Sitch, S.; Wang, T. The carbon balance of terrestrial ecosystems in China. Nature 2009, 458, 1009-1013. [CrossRef]

25. Kaminski, T.; Scholze, M.; Vossbeck, M.; Knorr, W.; Buchwitz, M.; Reuter, M. Constraining a terrestrial biosphere model with remotely sensed atmospheric carbon dioxide. Remote Sens. Environ. 2017, 203, 109-124. [CrossRef]

26. Chevallier, F.; Palmer, P.I.; Feng, L.; Boesch, H.; O’Dell, C.W.; Bousquet, P. Toward robust and consistent regional $\mathrm{CO}_{2}$ flux estimates from in situ and spaceborne measurements of atmospheric $\mathrm{CO}_{2}$. Geophys. Res. Lett. 2014, 41, 1065-1070. [CrossRef]

27. Deng, F.; Jones, D.B.A.; Henze, D.K.; Bousserez, N.; Bowman, K.W.; Fisher, J.B.; Nassar, R.; O’Dell, C.; Wunch, D.; Wennberg, P.O.; et al. Inferring regional sources and sinks of atmospheric $\mathrm{CO}_{2}$ from GOSAT $\mathrm{XCO}_{2}$ data. Atmos. Chem. Phys. 2014, 14, 3703-3727. [CrossRef]

28. He, Z.; Zeng, Z.-C.; Lei, L.; Bie, N.; Yang, S. A Data-Driven Assessment of Biosphere-Atmosphere Interaction Impact on Seasonal Cycle Patterns of $\mathrm{XCO}_{2}$ Using GOSAT and MODIS Observations. Remote Sens. 2017, 9 , 251. [CrossRef]

29. Ishizawa, M.; Mabuchi, K.; Shirai, T.; Inoue, M.; Morino, I.; Uchino, O.; Yoshida, Y.; Belikov, D.; Maksyutov, S. Inter-annual variability of summertime $\mathrm{CO}_{2}$ exchange in Northern Eurasia inferred from GOSAT $\mathrm{XCO}_{2}$. Environ. Res. Lett. 2016, 11, 105001. [CrossRef]

30. Detmers, R.G.; Hasekamp, O.; Aben, I.; Houweling, S.; van Leeuwen, T.T.; Butz, A.; Landgraf, J.; Köhler, P.; Guanter, L.; Poulter, B. Anomalous carbon uptake in Australia as seen by GOSAT. Geophys. Res. Lett. 2015, 42, 8177-8184. [CrossRef]

31. He, Z.; Lei, L.; Welp, L.; Zeng, Z.-C.; Bie, N.; Yang, S.; Liu, L. Detection of Spatiotemporal Extreme Changes in Atmospheric $\mathrm{CO}_{2}$ Concentration Based on Satellite Observations. Remote Sens. 2018, 10, 839. [CrossRef]

32. Parazoo, N.C.; Bowman, K.; Frankenberg, C.; Lee, J.-E.; Fisher, J.B.; Worden, J.; Jones, D.B.A.; Berry, J.; Collatz, G.J.; Baker, I.T.; et al. Interpreting seasonal changes in the carbon balance of southern Amazonia using measurements of $\mathrm{XCO}_{2}$ and chlorophyll fluorescence from GOSAT. Geophys. Res. Lett. 2013, 40, 2829-2833. [CrossRef]

33. Houweling, S.; Baker, D.; Basu, S.; Boesch, H.; Butz, A.; Chevallier, F.; Deng, F.; Dlugokencky, E.J.; Feng, L.; Ganshin, A.; et al. An intercomparison of inverse models for estimating sources and sinks of $\mathrm{CO}_{2}$ using GOSAT measurements. J. Geophys. Res. Atmos. 2015, 120, 5253-5266. [CrossRef]

34. Basu, S.; Baker, D.F.; Chevallier, F.; Patra, P.K.; Liu, J.; Miller, J.B. The impact of transport model differences on $\mathrm{CO}_{2}$; surface flux estimates from OCO-2 retrievals of column average $\mathrm{CO}_{2}$. Atmos. Chem. Phys. 2018, 18, 7189-7215. [CrossRef]

35. Houweling, S.; Aben, I.; Breon, F.M.; Chevallier, F.; Deutscher, N.; Engelen, R.; Gerbig, C.; Griffith, D.; Hungershoefer, K.; Macatangay, R.; et al. The importance of transport model uncertainties for the estimation of $\mathrm{CO}_{2}$ sources and sinks using satellite measurements. Atmos. Chem. Phys. 2010, 10, 9981-9992. [CrossRef]

36. Liu, J.; Bowman, K.W.; Lee, M.; Henze, D.K.; Bousserez, N.; Brix, H.; Collatz, G.J.; Menemenlis, D.; Ott, L.; Pawson, S.; et al. Carbon monitoring system flux estimation and attribution: Impact of ACOS-GOSAT $\mathrm{XCO}_{2}$ sampling on the inference of terrestrial biospheric sources and sinks. Tellus B 2014, 66. [CrossRef] 
37. Baker, D.F.; Law, R.M.; Gurney, K.R.; Rayner, P.; Peylin, P.; Denning, A.S.; Bousquet, P.; Bruhwiler, L.; Chen, Y.H.; Ciais, P.; et al. TransCom 3 inversion intercomparison: Impact of transport model errors on the interannual variability of regional $\mathrm{CO}_{2}$ fluxes, 1988-2003. Glob. Biogeochem. Cycles 2006, 20. [CrossRef]

38. Huete, A.; Justice, C.; Leeuwen, W.V. MODIS Vegetation Index (MOD13). Algorithm Theor. Basis Doc. 1999, $3,213$.

39. Pinzon, J.; Tucker, C. A Non-Stationary 1981-2012 AVHRR NDVI3g Time Series. Remote Sens. 2014, 6, 6929-6960. [CrossRef]

40. Myneni, R.B.; Knyazikhin, Y.; Park, T. MCD15A3H MODIS/Terra+Aqua Leaf Area Index/FPAR 4-day L4 Global $500 m$ SIN Grid V006 [Data set]; NASA EOSDIS Land Processes DAAC: Washington, DC, USA, 2015. [CrossRef]

41. Claverie, M.; Matthews, J.; Vermote, E.; Justice, C. A 30+ Year AVHRR LAI and FAPAR Climate Data Record: Algorithm Description and Validation. Remote Sens. 2016, 8, 263. [CrossRef]

42. Running, S.W.; Mu, Q.; Zhao, M. MOD17A2H MODIS/Terra Gross Primary Productivity 8-Day L4 Global 500m SIN Grid V006 [Data set]; NASA EOSDIS Land Processes DAAC: Washington, DC, USA, 2015. [CrossRef]

43. Reuter, M.; Bovensmann, H.; Buchwitz, M.; Burrows, J.P.; Connor, B.J.; Deutscher, N.M.; Griffith, D.W.T.; Heymann, J.; Keppel-Aleks, G.; Messerschmidt, J.; et al. Retrieval of atmospheric $\mathrm{CO}_{2}$ with enhanced accuracy and precision from SCIAMACHY: Validation with FTS measurements and comparison with model results. J. Geophys. Res. 2011, 116. [CrossRef]

44. Reuter, M.; Buchwitz, M.; Schneising, O.; Heymann, J.; Bovensmann, H.; Burrows, J.P. A method for improved SCIAMACHY $\mathrm{CO}_{2}$ retrieval in the presence of optically thin clouds. Atmos. Meas. Tech. 2010, 3, $209-232$. [CrossRef]

45. O’Dell, C.W.; Connor, B.; Bösch, H.; O’Brien, D.; Frankenberg, C.; Castano, R.; Christi, M.; Eldering, D.; Fisher, B.; Gunson, M.; et al. The ACOS $\mathrm{CO}_{2}$ retrieval algorithm-Part 1: Description and validation against synthetic observations. Atmos. Meas. Tech. 2012, 5, 99-121. [CrossRef]

46. Wunch, D.; Wennberg, P.O.; Osterman, G.; Fisher, B.; Naylor, B.; Roehl, C.M.; O'dell, C.; Mandrake, L.; Viatte, C.; Kiel, M.; et al. Comparisons of the Orbiting Carbon Observatory-2 (OCO-2) $\mathrm{XCO}_{2}$ measurements with TCCON. Atmos. Meas. Tech. 2017, 10, 2209-2238. [CrossRef]

47. Peters, W.; Jacobson, A.R.; Sweeney, C.; Andrews, A.E.; Conway, T.J.; Masarie, K.; Miller, J.B.; Bruhwiler, L.M.; Petron, G.; Hirsch, A.I.; et al. An atmospheric perspective on North American carbon dioxide exchange: CarbonTracker. Proc. Natl. Acad. Sci. USA 2007, 104, 18925-18930. [CrossRef]

48. Chevallier, F.; Ciais, P.; Conway, T.J.; Aalto, T.; Anderson, B.E.; Bousquet, P.; Brunke, E.G.; Ciattaglia, L.; Esaki, Y.; Fröhlich, M.; et al. $\mathrm{CO}_{2}$ surface fluxes at grid point scale estimated from a global 21 year reanalysis of atmospheric measurements. J. Geophys. Res. 2010, 115. [CrossRef]

49. Nassar, R.; Jones, D.B.A.; Suntharalingam, P.; Chen, J.M.; Andres, R.J.; Wecht, K.J.; Yantosca, R.M.; Kulawik, S.S.; Bowman, K.W.; Worden, J.R.; et al. Modeling global atmospheric $\mathrm{CO}_{2}$ with improved emission inventories and $\mathrm{CO}_{2}$ production from the oxidation of other carbon species. Geosci. Model Dev. 2010, 3, 689-716. [CrossRef]

50. Song, X.-P.; Hansen, M.C.; Stehman, S.V.; Potapov, P.V.; Tyukavina, A.; Vermote, E.F.; Townshend, J.R. Global land change from 1982 to 2016. Nature 2018, 560, 639-643. [CrossRef]

51. Oda, T.; Maksyutov, S. A very high-resolution $(1 \mathrm{~km} \times 1 \mathrm{~km})$ global fossil fuel $\mathrm{CO}_{2}$ emission inventory derived using a point source database and satellite observations of nighttime lights. Atmos. Chem. Phys. 2011, 11, 543-556. [CrossRef]

52. Wan, Z.; Hook, S.; Hulley, G. MOD11C2 MODIS/Terra Land Surface Temperature and the Emissivity 8-Day L3 Global 0.05Deg CMG V006 [Data set]; NASA EOSDIS LP DAAC: Washington, DC, USA, 2015. [CrossRef]

53. Huffman, G.J.; Bolvin, D.T.; Nelkin, E.J.; Wolff, D.B.; Adler, R.F.; Gu, G.; Hong, Y.; Bowman, K.P.; Stocker, E.F. The TRMM Multisatellite Precipitation Analysis (TMPA): Quasi-Global, Multiyear, Combined-Sensor Precipitation Estimates at Fine Scales. J. Hydrometeorol. 2007, 8, 38-55. [CrossRef]

54. Gorelick, N.; Hancher, M.; Dixon, M.; Ilyushchenko, S.; Thau, D.; Moore, R. Google Earth Engine: Planetary-scale geospatial analysis for everyone. Remote Sens. Environ. 2017, 202, 18-27. [CrossRef]

55. Jeong, S.-J.; Ho, C.-H.; Gim, H.-J.; Brown, M.E. Phenology shifts at start vs. end of growing season in temperate vegetation over the Northern Hemisphere for the period 1982-2008. Glob. Chang. Biol. 2011, 17, 2385-2399. [CrossRef] 
56. Zhang, X.; Friedl, M.A.; Schaaf, C.B. Global vegetation phenology from Moderate Resolution Imaging Spectroradiometer (MODIS): Evaluation of global patterns and comparison with in situ measurements. J. Geophys. Res. Biogeosci. 2006, 111. [CrossRef]

57. Zhang, X.; Friedl, M.A.; Schaaf, C.B.; Strahler, A.H.; Hodges, J.C.F.; Gao, F.; Reed, B.C.; Huete, A. Monitoring vegetation phenology using MODIS. Remote Sens. Environ. 2003, 84, 471-475. [CrossRef]

58. He, Z.; Lei, L.; Zhang, Y.; Sheng, M.; Wu, C.; Li, L.; Zeng, Z.-C.; Welp, L.R. Spatio-temporal mapping of multi-satellite observed column atmospheric $\mathrm{CO}_{2}$ using precision-weighted kriging method. Remote Sens. 2020, 12, 576. [CrossRef]

59. Burrows, J.P.; Hölzle, E.; Goede, A.P.H.; Visser, H.; Fricke, W. SCIAMACHY—Scanning Imaging Absorption Spectrometer for Atmospheric Chartography. Proc. Spie 1991, 35, 146-154. [CrossRef]

60. Yoshida, Y.; Ota, Y.; Eguchi, N.; Kikuchi, N.; Nobuta, K.; Tran, H.; Morino, I.; Yokota, T. Retrieval algorithm for $\mathrm{CO}_{2}$ and $\mathrm{CH}_{4}$ column abundances from short-wavelength infrared spectral observations by the Greenhouse gases observing satellite. Atmos. Meas. Tech. 2011, 4, 717-734. [CrossRef]

61. Boesch, H.; Baker, D.; Connor, B.; Crisp, D.; Miller, C. Global Characterization of $\mathrm{CO}_{2}$ Column Retrievals from Shortwave-Infrared Satellite Observations of the Orbiting Carbon Observatory-2 Mission. Remote Sens. 2011, 3, 270-304. [CrossRef]

62. Wang, T.; Shi, J.; Jing, Y.; Zhao, T.; Ji, D.; Xiong, C. Combining $\mathrm{XCO}_{2}$ measurements derived from SCIAMACHY and GOSAT for potentially generating global $\mathrm{CO}_{2}$ maps with high spatiotemporal resolution. PLoS ONE 2014, 9, e105050. [CrossRef]

63. Zeng, Z.; Lei, L.; Hou, S.; Ru, F.; Guan, X.; Zhang, B. A Regional Gap-Filling Method Based on Spatiotemporal Variogram Model of Columns. IEEE Trans. Geosci. Remote Sens. 2014, 52, 3594-3603. [CrossRef]

64. Zeng, Z.-C.; Lei, L.; Strong, K.; Jones, D.B.A.; Guo, L.; Liu, M.; Deng, F.; Deutscher, N.M.; Dubey, M.K.; Griffith, D.W.T.; et al. Global land mapping of satellite-observed $\mathrm{CO}_{2}$ total columns using spatio-temporal geostatistics. Int. J. Digit. Earth 2016. [CrossRef]

65. Krol, M.; Houweling, S.; Bregman, B.; Broek, M.V.D.; Segers, A.; Velthoven, P.V.; Peters, W.; Dentener, F.; Bergamaschi, P. The two-way nested global chemistry-transport zoom model TM5: Algorithm and applications. Atmos. Chem. Phys. 2005, 5, 417-432. [CrossRef]

66. Connor, B.J.; Boesch, H.; Toon, G.; Sen, B.; Miller, C.; Crisp, D. Orbiting Carbon Observatory: Inverse method and prospective error analysis. J. Geophys. Res. Atmos. 2008, 113, 1-14. [CrossRef]

67. Kenea, S.T.; Labzovskii, L.D.; Goo, T.-Y.; Li, S.; Oh, Y.-S.; Byun, Y.-H. Comparison of Regional Simulation of Biospheric CO2 Flux from the Updated Version of CarbonTracker Asia with FLUXCOM and Other Inversions over Asia. Remote Sens. 2020, 12, 145. [CrossRef]

68. Giglio, L.; Randerson, J.T.; van der Werf, G.R. Analysis of daily, monthly, and annual burned area using the fourth-generation global fire emissions database (GFED4). J. Geophys. Res. Biogeosci. 2013, 118, 317-328. [CrossRef]

69. Stocker, T.; Qin, D.; Plattner, G.; Tignor, M.; Allen, S.; Boschung, J.; Nauels, A.; Xia, Y.; Bex, B.; Midgley, B. IPCC, 2013: Climate Change 2013: The Physical Science Basis. In Contribution of Working Group I to the Fifth Assessment Report of the Intergovernmental Panel on Climate Change; Cambridge University Press: Cambridge, UK, 2013.

70. Wunch, D.; Wennberg, P.O.; Messerschmidt, J.; Parazoo, N.C.; Toon, G.C.; Deutscher, N.M.; Keppel-Aleks, G.; Roehl, C.M.; Randerson, J.T.; Warneke, T.; et al. The covariation of Northern Hemisphere summertime $\mathrm{CO}_{2}$ with surface temperature in boreal regions. Atmos. Chem. Phys. 2013, 13, 9447-9459. [CrossRef]

71. Wunch, D.; Wennberg, P.O.; Toon, G.C.; Connor, B.J.; Fisher, B.; Osterman, G.B.; Frankenberg, C.; Mandrake, L.; O'Dell, C.; Ahonen, P.; et al. A method for evaluating bias in global measurements of $\mathrm{CO}_{2}$ total columns from space. Atmos. Chem. Phys. 2011, 11, 12317-12337. [CrossRef]

72. Wunch, D.; Toon, G.C.; Blavier, J.F.; Washenfelder, R.A.; Notholt, J.; Connor, B.J.; Griffith, D.W.; Sherlock, V.; Wennberg, P.O. The total carbon column observing network. Philos. Trans. Ser. AMath. Phys. Eng. Sci. 2011, 369, 2087-2112. [CrossRef]

73. Zhang, Q. The South-to-North Water Transfer Project of China: Environmental Implications and Monitoring Strategy. JAWRA J. Am. Water Resour. Assoc. 2009, 45, 1238-1247. [CrossRef]

74. Liu, J.; Zhang, Z.; Xu, X.; Kuang, W.; Zhou, W.; Zhang, S.; Li, R.; Yan, C.; Yu, D.; Wu, S.; et al. Spatial patterns and driving forces of land use change in China during the early 21st century. J. Geogr. Sci. 2010, 20, 483-494. [CrossRef] 
75. Liu, J.; Liu, M.; Tian, H.; Zhuang, D.; Zhang, Z.; Zhang, W.; Tang, X.; Deng, X. Spatial and temporal patterns of China's cropland during 1990-2000: An analysis based on Landsat TM data. Remote Sens. Environ. 2005, 98, 442-456. [CrossRef]

76. Lu, C.; Tian, H. Global nitrogen and phosphorus fertilizer use for agriculture production in the past half century: Shifted hot spots and nutrient imbalance. Earth Syst. Sci. Data 2017, 9, 1-33. [CrossRef]

77. Song, Y.; Linderholm, H.W.; Chen, D.; Walther, A. Trends of the thermal growing season in China, 1951-2007. Int. J. Climatol. 2009, 33-43. [CrossRef]

78. Saeki, T.; Patra, P.K. Implications of overestimated anthropogenic $\mathrm{CO}_{2}$ emissions on East Asian and global land $\mathrm{CO}_{2}$ flux inversion. Geosci. Lett. 2017, 4. [CrossRef]

79. Yu, G.; Chen, Z.; Piao, S.; Peng, C.; Ciais, P.; Wang, Q.; Li, X.; Zhu, X. High carbon dioxide uptake by subtropical forest ecosystems in the East Asian monsoon region. Proc. Natl. Acad. Sci. USA 2014, 111, 4910-4915. [CrossRef]

80. Canadell, J.; Pataki, D.E.; Gifford, R.M.; Houghton, R.A.; Luo, Y.; Raupach, M.R.; Smith, P.; Steffen, W. Saturation of the terrestrial carbon sink. In Terrestrial Ecosystems in a Changing World; Springer: Berlin/Heidelberg, Germany, 2006.

81. Pillai, D.; Gerbig, C.; Kretschmer, R.; Beck, V.; Karstens, U.; Neininger, B.; Heimann, M. Comparing Lagrangian and Eulerian models for $\mathrm{CO}_{2}$ transport-A step towards Bayesian inverse modeling using WRF/STILT-VPRM. Atmos. Chem. Phys. 2012, 12, 8979-8991. [CrossRef]

82. Dayalu, A.; Munger, J.W.; Wofsy, S.C.; Wang, Y.; Nehrkorn, T.; Zhao, Y.; McElroy, M.B.; Nielsen, C.P.; Luus, K. Assessing biotic contributions to $\mathrm{CO}_{2}$ fluxes in northern China using the Vegetation, Photosynthesis and Respiration Model (VPRM-CHINA) and observations from 2005 to 2009. Biogeosciences 2018, 15, 6713-6729. [CrossRef]

(C) 2020 by the authors. Licensee MDPI, Basel, Switzerland. This article is an open access article distributed under the terms and conditions of the Creative Commons Attribution (CC BY) license (http://creativecommons.org/licenses/by/4.0/). 